\title{
O DEBATE SOBRE O ABORTO NAS CÂMARAS DOS DEPUTADOS DO BRASIL E DO URUGUAI (1985-2016)
}

\section{Luis Gustavo Teixeira da Silva (D)}

E-mail: gustavoteixeira2519@gmail.com

Departamento de Sociologia e Política da Universidade Federal de Pelotas (UFPel), Pelotas - RS, Brasil.

DOI: $10.1590 / 3610607 / 2021$

\section{Introdução}

A redemocratização nos países da América Latina tornou possível, em maior ou menor medida, a realização de discussóes no ambiente parlamentar de temas até então censurados e/ou circunscritos a esferas das organizações da sociedade civil. Nesse contexto, sem a iminência de um ente repressor, os movimentos sociais passaram a reivindicar suas demandas ao Estado. Na esteira desses processos, as mobilizaçóes dos movimentos feministas consolidaram sua agenda de reivindicação ao sistema político de autonomia e direitos sociais relacionados às desigualdades de gênero. A partir disso, o direito ao aborto foi paulatinamente inscrito no rol de discussóes do Poder Legislativo nos países da região, mas registrando variações no modo de deliberação do assunto nas casas legislativas.

Artigo recebido em: 04/04/2020

Aprovado em: 14/09/2020
Diante desse panorama, o objetivo deste texto é analisar e comparar o debate legislativo no Brasil e no Uruguai sobre o aborto. Para realizar essa investigação utilizamos como metodologia de pesquisa a análise de todos os pronunciamentos proferidos na Câmara dos Deputados do Brasil e na Câmara de Representantes do Uruguai, entre os anos de 1985 e 2016. A comparação entre esses países é relevante por se constituírem em casos opostos, no tocante ao tratamento dos direitos reprodutivos das mulheres. O Uruguai se tornou o único país da regiāo, em período recente, a aprovar uma legislação para descriminalizar da interrupção voluntária da gravidez. Já no Brasil verifica-se a ascensão de forças políticas, sociais e religiosas conservadoras, as quais são, em grande medida, responsáveis por conduzir de modo regressivo a discussão sobre o aborto no Poder Legislativo. Nesse sentido, nossa proposta é examinar os dados e apresentar indicadores relativos às dinâmicas político-sociais para explicar a composição das posiçóes em disputa, assim como 
mensurar o papel da laicidade do Estado para avaliar esses distintos cenários, já que esse princípio é vital às sociedades plurais e democráticas, pois sua função é assegurar a liberdade de consciência e a neutralidade das instituiçóes do Estado frente a crenças.

O texto é subdividido em três seções, inicialmente explicamos os principais elementos metodológicos adotados para a realização da pesquisa, sobretudo os parâmetros de comparação e os procedimentos de coleta e análise dos pronunciamentos. $\mathrm{Na}$ segunda seção, analisamos o modo como as posiçôes sobre o aborto foram expressas nos pronunciamentos, assim como sua distribuição durante o período estudado. $\mathrm{Na}$ terceira seçáo, examinamos os argumentos mobilizados pelos(as) parlamentares para sustentar suas posiçóes.

\section{Metodologia da pesquisa}

A metodologia da pesquisa se baseou na análise dos pronunciamentos sobre o aborto, proferidos pelos(as) deputados(as) que compóem a Câmara dos Deputados do Brasil e a Câmara de Representantes do Uruguai, entre os anos de 1985 e 2016; logo, todas as manifestações de fala realizadas em plenário desde o início do governo civil até os dias atuais. $\mathrm{Na}$ investigação também analisamos, como material suplementar, as proposiçóes políticas (por exemplo, projetos de lei e emendas constitucionais) apresentadas e/ou apreciadas na Câmara dos Deputados do Brasil e na Câmara de Representantes do Uruguai, no mesmo período. A observação das proposiçóes políticas tem como papel primordial auxiliar na compreensão da deliberação, da forma de atuação dos(as) parlamentares e do teor das iniciativas propostas e/ou apreciadas em cada casa legislativa.

Este estudo foi iniciado em 2012 e se concentrou nos dados do legislativo brasileiro, coletados e analisados pelo grupo de pesquisa Democracia e Desigualdades, da Universidade de Brasília (UnB), no âmbito do projeto intitulado "Direito ao aborto e sentidos da maternidade: atores e posiçóes em disputa no Brasil contemporâneo".

O primeiro passo foi a seleção dos pronunciamentos que iriam compor a base de análise. Para isso, elaboramos um conjunto de palavras-chave que permitisse coletar as diferentes formas de construção da fala sobre o aborto. Após testes para experimentá-las no mecanismo de busca no site da Câmara dos Deputados do Brasil (Brasil, 2020b), a conclusão foi que os termos para rastreá-los seriam os seguintes: aborto, abortamento, interrupção voluntária da gravidez, interrupção da gravidez, interrupção voluntária da gestação e interrupção da gestação. A partir desses procedimentos, coletamos e analisamos 1.078 discursos, proferidos entre janeiro de 1985 e dezembro de 2016. Os dados correspondem ao período da $47^{\text {a }}$ legislatura até a $55^{\text {a }}$ legislatura. Do mesmo modo, analisamos no referido período sessenta proposiçôes com enfoque na alteração da legislação brasileira, seja para ampliar, regulamentar ou restringir o aborto.

A pesquisa na Câmara de Representantes do Uruguai foi efetuada a partir de 2014, após a conclusão parcial realizada na Câmara dos Deputados do Brasil. Desse modo, na Câmara de Representantes do Uruguai foram coletados e analisados 337 discursos, proferidos entre janeiro de 1985 e dezembro de 2016, da 42a legislatura até a $48^{a}$ legislatura, bem como dez projetos de lei apresentados e/ou apreciados nesse período.

Para estabelecer uma análise comparativa, foram adotados os mesmos procedimentos, salvo por pequenas adequaçóes executadas, principalmente idiomáticas. A comparação foi realizada a partir de alguns parâmetros. Em primeiro lugar, foi efetuada com base em um recorte espacial específico, isto é, a análise dos pronunciamentos proferidos em uma esfera do Poder Legislativo, a Câmara dos Deputados (Uruguay, 2016). Em segundo, foi também aplicado um recorte temático, ou seja, entre os diversos assuntos que compóem a agenda parlamentar, selecionamos os discursos sobre o aborto. Por último, o recorte temporal foi equivalente para ambos os países. Portanto, apesar das enormes diferenças, por exemplo, demográficas, territoriais e sociais entre Brasil e Uruguai, tais recortes viabilizam a análise comparativa pelo fato de nos concentrarmos no material produzido pelos(as) representantes políticos(as) de uma instituição do Estado circunscrita com função similar no regime democrático.

Esta investigação poderia também ser baseada nos pronunciamentos realizados no Senado, outra esfera do Poder Legislativo. A decisão de não os incorporar neste trabalho foi motivada por razóes relacionadas ao caso brasileiro. O tamanho da amostra foi preponderante na opção de apresentar 
os dados da Câmara dos Deputados, haja vista que entre 1985 e 2016 foram proferidos no Senado Federal do Brasil apenas oitenta discursos sobre o aborto, realizados de modo disperso, sem que fosse efetuada uma discussão sobre legislação específica; situação distinta ao caso uruguaio, em que foram proferidos 110 discursos com base em três projetos de lei sobre a interrupção voluntária da gravidez. É necessário destacar dois trabalhos relevantes na análise dos pronunciamentos realizados na Câmara de Senadores do Uruguai: Daniel Jones (2007) examina a deliberação sobre a Ley de Salud Reproductiva, de 2004, e Susana Rostagnol (2008) que aborda a discussáo no Senado em torno do projeto de lei Defensa del Derecho a la Salud Sexual y Reproductiva, realizado em 2007. Portanto, o tamanho e o conteúdo das falas no Senado Federal do Brasil poderiam inviabilizar uma análise comparativa com o Uruguai. Dito isso e tendo em vista a impossibilidade de analisar os dados das duas casas em conjunto, por demandar espaço ainda maior, e pelo fato de que utilizar as falas do Senado Federal, em detrimento dos enunciados na Câmara dos Deputados do Brasil, poderia reduzir significativamente o volume dos dados analisados, optamos por restringir o alcance das evidências acerca das posiçóes e disputas em torno do aborto.

Após o processo de seleção, todos os pronunciamentos foram lidos e analisados. Para cada discurso, uma ficha no software estatístico Sphinx Lexica ${ }^{1}$ foi preenchida, com 32 variáveis de classificação dos discursos (ver modelo utilizado no anexo I). As variáveis nessa ficha foram elaboradas de acordo com testes realizados pelas(os) integrantes da pesquisa.

A utilização desse instrumento foi de suma importância à sistematização das informaçóes, realizada em três etapas. A primeira etapa consistiu na documentação da fala parlamentar, com o registro de página e expediente para Brasil (BR) e de sessão plenária para Uruguai (UY), bem como data do discurso nos Diários da Câmara dos Deputados e dos Representantes. Na segunda etapa, foram registradas as informaçóes de identificação do(a) parlamentar pronunciante: nome, sexo, filiação partidária, unidade federativa (BR) ou departamento (UY) pelo qual foi eleito(a), e número de mandatos exercidos. A última etapa consistiu em classificar o conteúdo expresso em cada discurso: as palavras-chave mencionadas na fala; a centralidade com que o tema do aborto foi tratado no pronunciamento; a posição sobre o assunto; a posição específica (tipo de ampliação ou restrição ao aborto); os argumentos empregados para sustentar sua posição; $o$ argumento principal da fala; o contra-argumento, ou seja, o(s) argumento(s) que o(a) parlamentar buscou contestar e/ou refutar; a autoidentificação utilizada como argumento de autoridade para pontuar um lugar de fala (por exemplo, mãe, mulher, médico, sacerdote etc.); a especificação de algum fato do momento sobre o qual o pronunciamento se baseou, interno e/ou externo à atividade legislativa; ${ }^{2}$ por fim, o arquivamento do discurso e das observaçóes sobre ele. O recurso tornou exequível a sistematização e o cruzamento dos dados obtidos, do mesmo modo, a construção de panoramas qualitativos e quantitativos de um material composto essencialmente de textos. (Para mais detalhes sobre os procedimentos em nota de pesquisa, ver Silva, 2017a.)

Nesta análise comparativa, precisamos levar em consideração o contexto em que os discursos foram proferidos. Esse aspecto é um componente relevante no entendimento de alguns fatores relativos às diferenças entre os países, como: (1) a legislação vigente acerca da interrupção voluntária da gravidez; (2) a composição das casas parlamentares; e (3) os formatos das sessóes legislativas para a elaboração dos discursos. Assim, antes de examinar os dados, convém ilustrar a base legal e institucional sobre a qual se estruturou os discursos.

No Brasil o Código Penal de 1940, promulgado pelo Decreto-Lei n. 2.848, estabeleceu os dispositivos jurídicos sobre o aborto, em grande parte, vigentes até os dias atuais. Nessa legislação o ato é enquadrado entre os crimes contra a pessoa e a vida, com puniçôes ao aborto provocado pela gestante e por terceiros; as exceçóes de punibilidade para essa lei estão no artigo 128: a ausência de punição quando provocado por médico na circunstância em que não há outro meio para salvar a vida da mãe e quando a gestação é resultado de estupro. Em 2012 os(as) ministros(as) do Supremo Tribunal Federal (STF) incorporaram outra exceção de punibilidade à legislação: a descriminalização do aborto de fetos diagnosticados com anencefalia (Diniz e Vélez, 2008).

No Uruguai o aborto se tornou delito e criminalizado por meio da Lei n. 9.763 de 1938. Essa legislação abarcou um número amplo de exceções sobre as quais não se aplicava qualquer tipo de pena, desde 
que o aborto fosse realizado por um médico. Entre as exceçóes de punibilidade dessa lei estão: gravidez com risco de saúde ou vida da mulher; gravidez decorrente de violência sexual (estupro); penúria econômica e honra (art. 328, incisos 1-5) (Htun, 2003). Essa legislação vigorou até 2012, quando a interrupção voluntária da gravidez foi descriminalizada.

Do ponto de vista institucional, em primeiro lugar, precisamos pontuar que no Brasil são eleitos(as) 513 deputados(as) federais para o exercício do mandato em legislatura com duração de quatro anos. No Uruguai são eleitos 99 deputados(as) à Câmara de Representantes para legislatura com duração de cinco anos. Essa composição foi, em parte, constante entre 1985 e 2016, explicando a proporção dos discursos pronunciados em cada país.

Por outro lado, é necessário verificar os espaços destinados ao exercício da palavra no âmbito parlamentar. No Brasil, os(as) deputados(as) dispóem de cinco sessôes plenárias diárias para se pronunciar, são elas: Grande Expediente, Pequeno Expediente, Comunicações Parlamentares, Comunicações das Lideranças e Ordem do Dia (Brasil, 2012b). As três primeiras sessões ordinárias são livres e sem temática específica, já as duas últimas exigem precondiçóes, como ser líder do partido (mesmo que cedendo essa prerrogativa a outro(a) parlamentar) e discursar acerca de uma temática focada. No legislativo uruguaio há três sessôes plenárias: ordinárias, extraordinárias e especiais. Nelas é discutido apenas o roteiro previamente estabelecido da ordem do dia. Para discursar sobre algum tema que não está na ordem do dia, os(as) parlamentares podem realizar as Exposiciones Verbales, durante a media hora previa, composta de até seis discursos de, no máximo, cinco minutos (Uruguay, 2014, art. 153-154). Logo, os(as) parlamentares discursaram sobre o assunto preponderantemente quando esteve na ordem do dia.

Essas ponderaçóes têm por propósito indicar as distintas realidades que compóem o ambiente desta investigação e os parâmetros em que se estabelece a análise comparativa. A partir disso, sinalizamos que neste texto vamos nos concentrar em dois aspectos: (1) na posição dos(as) parlamentares sobre o aborto e (2) quais argumentos foram mobilizados e sua relação com as posiçóes sustentadas.

\section{As posiçóes assumidas nos discursos}

Nesta etapa, o objetivo é expor o diagnóstico dos dados aferidos a respeito das posiçóes expressas nos discursos sobre o aborto, bem como explorar configuraçôes peculiares contidas nesses posicionamentos. Para isso, inicialmente apresentamos a tabela $1 \mathrm{com}$ o mapeamento geral das posiçóes, cujos resultados foram obtidos por meio da variável de número 16 - O discurso se coloca, composta de seis categorias de posicionamento dos(as) parlamentares; em

Tabela 1

Distribuição dos discursos (quantidade de citaçóes e porcentagem) de acordo com a posiçáo dos(as) parlamentares sobre o aborto no Brasil e no Uruguai (1985-2016)

\begin{tabular}{|c|c|c|c|c|}
\hline \multirow{2}{*}{$\begin{array}{c}\text { País } \rightarrow \\
\text { Posiçáo } \downarrow\end{array}$} & \multicolumn{2}{|c|}{ BRASIL } & \multicolumn{2}{|c|}{ URUGUAI } \\
\hline & Q. & $\%$ & Q. & $\%$ \\
\hline A favor da ampliaçáo do aborto legal & 178 & $16,5 \%$ & 167 & $49,6 \%$ \\
\hline A favor da manutençáo da lei & 202 & $18,8 \%$ & 66 & $19,6 \%$ \\
\hline A favor da restrição do aborto legal & 168 & $15,6 \%$ & 2 & $0,6 \%$ \\
\hline Contra o aborto (genérico) & 423 & $39,3 \%$ & 91 & $27,0 \%$ \\
\hline Por novas medidas punitivas e/ou de controle & 137 & $12,7 \%$ & 1 & $0,3 \%$ \\
\hline Pela educação sexual e/ou planejamento familiar & 129 & $12,0 \%$ & 54 & $16,0 \%$ \\
\hline Total & 1.237 & - & 381 & - \\
\hline
\end{tabular}

Fonte: Elaboração própria com base nos dados do projeto "Direito ao aborto e os sentidos da maternidade: atores e posiçóes em disputa no Brasil contemporâneo", financiado pelo edital MCTI/CNPq/SPM-PR/MDA n. 32/2012. Observaçáo: A porcentagem é calculada a partir do número total de discursos (337 no Uruguai e 1.078 no Brasil), por isso a soma ultrapassa $100 \%$, devido à possibilidade de duas respostas em cada questão. 
cada pronunciamento era possível marcar até duas alternativas.

Para iniciar a análise dos dados, passamos a considerar a categoria a favor da ampliação ao aborto legal. Ao examinar a tabela 1 notamos que no Uruguai quase metade de todos os pronunciamentos em plenário sustentou essa posição, além do mais, percebemos que esse percentual de 49,6\% a favor da ampliação ao aborto legal é muito superior em relação às demais categorias. No Brasil essa posição foi assumida em $16,5 \%$ dos discursos; considerando as categorias uma a uma, essa proporção pode ser avaliada como mediana no quadro geral. Não obstante, sua expressão se torna periférica quando comparada a todos os pronunciamentos cujas posiçóes estão situadas no espectro de oposição a políticas em prol da interrupção voluntária da gravidez identificada pelas categorias contra o aborto (genérico), a favor da restriçáo do aborto legal e por novas medidas punitivas elou de controle, que somadas atingem $67,6 \%$ dos discursos.

$\mathrm{O}$ índice de posicionamentos a favor da ampliação do aborto legalé um indicador muito representativo da composiçấo do debate legislativo em cada país, assim como na comparação entre eles. Esse dado permite constatar uma tendência acerca dos diferentes níveis de adesão pela ampliação dos direitos reprodutivos das mulheres na Câmara dos Deputados do Brasil e na Câmara de Representantes do Uruguai.

A magnitude desses percentuais pode ser aperfeiçoada, isso porque para cada discurso apontado com a posição a favor da ampliação do aborto legal, era necessário classificar na variável 17 a natureza ou o tipo de ampliação indicado no pronunciamento, composta de cinco categorias; em cada discurso era possível assinalar até quatro alternativas. $\mathrm{Na}$ tabela 2 apresentamos os resultados obtidos por essa classificação, em números absolutos e percentuais. Nela também consta o número de projetos de lei (e outras modalidades de proposiçóes legislativas - PLs) apresentados e/ou apreciados nas respectivas casas legislativas, com o intuito de alterar e/ou regulamentar a legislação no sentido de ampliar o direito ao aborto.

Por intermédio desse exercício, notamos que os números sobre o tipo de ampliação pela descriminalizaçâo total aprofundam ainda mais as diferenças nos discursos proferidos nos respectivos países. Levando em consideração o total de discursos no Brasil, aqueles que apontaram como ampliação a descriminalização total equivalem a $7 \%$, já no Uruguai representam $42,5 \%$ do total. Nesse caso é preciso ponderar os contextos, primeiramente notar que 291 discursos proferidos na Câmara de Representantes do Uruguai (86,4\% do total de 337) foram efetuados em pleno processo de apreciação na ordem do dia de projetos de lei sobre a descriminalização do aborto, precisamente nos anos de 2002, 2008 e 2012. Já os pronunciamentos na Câmara dos Deputados do Brasil foram majoritariamente efetuados em sessóes de tema livre, sem a deliberação exclusiva sobre a descriminalização.

Em segundo lugar, consideramos importante avaliar os baixos índices de ampliação aferidos

Tabela 2

Distribuiçáo dos discursos (quantidade e porcentagem) e proposiçóes legislativas (PLs), de acordo com o tipo de ampliaçáo de acesso ao aborto no Brasil e no Uruguai (1985 e 2016)

\begin{tabular}{|c|c|c|c|c|c|c|}
\hline \multirow{2}{*}{$\begin{array}{c}\text { País } \rightarrow \\
\text { Ampliaçáo } \downarrow\end{array}$} & \multicolumn{3}{|c|}{ BRASIL } & \multicolumn{3}{|c|}{ URUGUAI } \\
\hline & Q. & $\%$ & PLs & Q. & $\%$ & PLs \\
\hline Descriminalização total & 75 & $7,0 \%$ & 10 & 143 & $42,5 \%$ & 7 \\
\hline Permissão em caso de inviabilidade do feto & 29 & $2,7 \%$ & 3 & 5 & $1,5 \%$ & 0 \\
\hline Ampliação da assistência na rede hospitalar & 70 & $6,5 \%$ & 3 & 10 & $3,0 \%$ & 1 \\
\hline Não indica que tipo de ampliação & 28 & $2,6 \%$ & 0 & 16 & $4,8 \%$ & 0 \\
\hline Outro & 5 & $0,6 \%$ & 8 & 3 & $0,9 \%$ & 1 \\
\hline Total & 207 & - & 24 & 177 & - & 9 \\
\hline
\end{tabular}

Fonte: Elaboração própria com base nos dados do projeto "Direito ao aborto e os sentidos da maternidade: atores e posiçóes em disputa no Brasil contemporâneo", financiado pelo edital MCTI/CNPq/SPM-PR/MDA n. 32/2012. Observação: (1) A porcentagem é calculada a partir do número total de discursos (337 no Uruguai e 1.078 no Brasil); (2) era possível assinalar até quatro alternativas em cada questão. 
no Uruguai nas demais categorias. O Uruguai é historicamente um dos países referência na América Latina na promoção e no acesso a serviços de saúde. A partir de 2004, com a promulgação da Resolução 369/04, houve a regulamentação dos serviços de saúde pré e pós-aborto (Rostagnol, 2009; Rocha et al., 2009). Logo, esses fatos permitem entender a baixa demanda nos discursos com relação à ampliação da assistência na rede hospitalar. Do mesmo modo, a categoria permissáo em caso de inviabilidade do feto apresenta poucos registros devido ao fato de que, em boa parte casos, essa situação se enquadrava na legislação vigente de 1938 até 2012, por representar algum tipo de risco à saúde ou à vida da gestante.

A realidade brasileira é constituída de outro cenário: o sistema de saúde pública é insuficiente para atender a enorme demanda e o sistema privado é inacessível à grande parcela da população. Mais que isso, as exceçôes previstas desde 1940, permissão em caso de estupro ou risco de vida à gestante, são até certo ponto esvaziadas e ineficazes em razão de burocracia e falta de atendimento e informação. As normas técnicas do Ministério da Saúde, de 1999 e 2005, foram tentativas de regulamentar e desburocratizar os serviços de atendimento e o acesso à interrupção da gravidez nos referidos casos. A antropóloga Debora Diniz (2003) demonstra que o usufruto desse direito envolve controversas disputas judiciais, bem como uma série de laudos médicos comprobatórios da violência e/ou do risco de vida da gestante.
$\mathrm{Na}$ tabela 3 adiante é possível verificar muitas iniciativas com o propósito de normatizar obstáculos à realização do aborto nos casos previstos na legislação. Nesse panorama, as demandas por ampliação da assistência na rede hospitalar e permissão em caso de inviabilidade do feto devem ser avaliadas como relevantes pontos no debate sobre o tema frente ao quadro do legislativo brasileiro. Dito isso, deve-se ter em vista que a ascensão de grupos conservadores na esfera política tornou regulamentaçóes e/ou ampliaçóes moderadas no direito ao aborto um empreendimento que exigiu (e exige) significativa mobilização entre distintas esferas do legislativo, do judiciário e da sociedade civil.

Essa ponderação possibilita entender os contextos em que os dados surgem e quando são comparados. Entretanto, tal reflexão não anula a grandeza das magnitudes aferidas, isto é, a constatação de que discussóes em plenário e projetos de lei a respeito das ampliaçóes do direito ao aborto no Brasil e no Uruguai buscaram atender a propósitos distintos.

Nesta pesquisa foram utilizadas três categorias para classificar as distintas formas de oposição à interrupção voluntária da gravidez, são elas: (1) contra o aborto (genérico), a qual foi assinalada naqueles discursos contrários ao aborto, mas que não tratavam da legislação, tampouco defendiam mudanças nela; (2) a favor da restrição do aborto legal, que foi empregada em situaçóes em que o(a) deputado(a) se posicionou

Tabela 3

Distribuiçáo dos discursos (quantidade de citaçóes e porcentagem) de acordo com o tipo de restriçáo sobre o aborto nos legislativos brasileiro e uruguaio (1985-2016)

\begin{tabular}{|c|c|c|c|c|c|c|}
\hline \multirow{2}{*}{$\begin{array}{c}\text { País } \rightarrow \\
\text { Restriçáo } \downarrow\end{array}$} & \multicolumn{3}{|c|}{ BRASIL } & \multicolumn{3}{|c|}{ URUGUAI } \\
\hline & Q. & $\%$ & PLs & Q. & $\%$ & PLs \\
\hline Proibição total & 103 & $9,6 \%$ & 9 & 1 & $0,3 \%$ & 0 \\
\hline Estupro & 40 & $3,8 \%$ & 3 & 0 & 0 & 0 \\
\hline Risco de vida da mãe & 3 & $0,3 \%$ & 0 & 0 & 0 & 0 \\
\hline Inviabilidade do feto & 16 & $1,5 \%$ & 3 & 1 & $0,3 \%$ & 0 \\
\hline Políticas de repressão ao aborto & 72 & $6,7 \%$ & 18 & 1 & $0,3 \%$ & 0 \\
\hline Não indica que tipo de restrição & 53 & $5 \%$ & 0 & 0 & 0 & 0 \\
\hline Outro & 12 & $1,1 \%$ & 3 & 0 & 0 & 3 \\
\hline Total & 299 & - & 36 & 3 & - & 1 \\
\hline
\end{tabular}

Fonte: Elaboração própria com base nos dados do projeto "Direito ao aborto e os sentidos da maternidade: atores e posiçóes em disputa no Brasil contemporâneo", financiado pelo edital MCTI/CNPq/SPM-PR/MDA n. 32/2012. Observação: (1) A porcentagem é calculada a partir do número total de discursos (337 no Uruguai e 1.078 no Brasil); (2) era possível assinalar até seis alternativas em cada questão. 
pela extinção de uma ou mais exceções de aborto legal previstas nas respectivas legislaçôes dos países; e (3) por novas medidas punitivas elou de controle, quando defendeu que nas situaçóes em que o aborto já era crime as penas deviam ser mais rigorosas ou haver maior controle para que não fosse realizado.

A posição contra o aborto (genérico) apresenta percentuais razoavelmente próximos no Brasil (38,4\%, 426) e no Uruguai $(27 \%, 91)$, representando os maiores números nos dois casos em relação às demais categorias de conteúdo similar. As nuances surgem ao analisar as duas últimas categorias. Dado que a soma delas, representam apenas $0,9 \%{ }^{3}$ dos discursos no Uruguai; já no Brasil a posição a favor da restrição do aborto legal foi sustentada em 15,2\% (168) dos pronunciamentos e a posição por novas medidas punitivas elou controle surgiu em 12,4\% (137).

Novamente é necessário refinar esses índices, pois cada vez que uma das posiçóes nos discursos era $a$ favor da restrição do aborto legal e/ou por novas medidas punitivas elou controle também era necessário pontuar, na variável 19 - Caso seja a favor da restrição do aborto legal e/ou por novas medidas punitivas, composta de seis categorias com possibilidade de assinalar até cinco alternativas, a qual tipo de restrição o discurso fazia menção. Na tabela abaixo apresentamos os resultados obtidos por essa classificação, em números absolutos e percentuais. Na tabela 3 constam os projetos de lei (e outras proposiçóes legislativas - PLs) apresentados e/ou apreciados nas respectivas casas legislativas com relação a esse conteúdo.

Mais uma vez, temos dois panoramas opostos quando desagregamos os dados. Nessa situação demonstramos que, quando realizamos o mesmo exercício sobre os tipos de restrição, os índices de posiçóes que apontaram para retrocessos na legislaçáo se reduziram no Uruguai e se ampliaram significativamente no Brasil. Nesse caso, a principal razão explicativa para os elevados índices no legislativo brasileiro de pronunciamentos e proposições políticas com conotações regressivas converge à constatação da consolidação de posições conservadoras entre os(as) parlamentares eleitos(as) para a Câmara dos Deputados.

No Uruguai há uma distribuição razoavelmente equilibrada entre as posiçóes sobre a matéria, todavia os posicionamentos em plenário com conteúdo restritivo e proposiçóes apresentadas são irrisórios no marco integral dos dados, sendo que a legislação do país era constituída de número maior de permissóes até 2012, como a realização do aborto em casos de penúria econômica e/ou quando representava risco à saúde da gestante. Essa verificação não está isenta de sofrer alteraçóes mais significativas em panoramas futuros, em virtude dos projetos de lei apresentados nos últimos anos; ${ }^{4}$ porém, até o momento de abrangência da pesquisa, os dados registrados nesse espectro do debate legislativo, de cunho restritivo, são insuficientemente representativos, salvo para ponderar mudanças no quadro.

A categoria pela educação sexual elou planejamento familiar serviu para classificar a posição em prol de políticas direcionadas à educação sexual de jovens e adultos e à elaboração/ampliação de programas e campanhas destinados à orientação sobre a importância do planejamento familiar. Esse posicionamento representa uma magnitude mediana no contexto geral em ambos os países. Mais importante que isso é perceber que tal posição nos discursos deflagra certa complexidade não identificada nas outras categorias, devido à heterogeneidade de direcionamentos e circunstâncias com que foi utilizada. Quer dizer, esse posicionamento foi empregado pelos(as) deputados(as) para se expressar a favor do aborto ou contra ele. No caso brasileiro, das 129 vezes em que foi assumida, essa posição foi mobilizada em 38 discursos junto com a posição a favor da ampliação do aborto legal, em 72 pronunciamentos junto a posicionamentos contrários (três categorias fundidas) e em treze pronunciamentos junto com a favor da manutenção da lei. No Uruguai, do total de 54 registros, aparece em dezenove discursos junto com a posição a favor da ampliaçấo do aborto legal, em vinte ao lado da categoria contra o aborto (genérico) e em nove junto com a favor da manutenção da lei.

Como podemos notar, em boa parte dos discursos a posição pela educação sexual elou planejamento familiar aparece com posicionamentos contrários. Nessa junção os(as) parlamentares tendem a argumentar que o aborto está associado à pobreza e, consequentemente, à ausência de políticas de educação sexual e planejamento familiar. Por isso a resposta para a questão do aborto, em vez $\mathrm{da}$ descriminalização, seria o investimento em políticas dessa natureza, que produziriam melhores 
resultados na diminuição da prática que, como pensam alguns desses(as) parlamentares, não respeita a vida e pode transformar o aborto em método contraceptivo.

Esse tipo de construção é frequente e, para ilustrar, apresentamos o excerto da fala do deputado federal Costa Ferreira (PP/PPB/PPR-MA):

A “interrupção voluntária da gravidez”, disfarce eufemístico que intenta fazer da prática macabra de dispor de vidas inocentes um ato normal, é, antes de tudo, assunto de educação e saúde pública. Nesse sentido, faço coro com a opinião lúcida da norte-americana Mary Ann Glendon, representante do Papa João Paulo II na Conferência de Pequim. Em entrevista à Folha de S. Paulo, a chefe da delegação do Vaticano afirma que os melhores contraceptivos são educação e desenvolvimento econômico.

No Brasil, porém, faltam meios para levar a informação às camadas menos favorecidas, para estabelecer uma programação permanente de educação sexual e de orientação quanto ao planejamento familiar (...). (Brasil, Diários da Câmara dos Deputados, 19 set. 1995, p. 22.553)

Nas duas casas legislativas podemos identificar respostas a esse tipo de formulação. Os (As) parlamentares indicam a inexistência de antagonismo entre as políticas educativas, a descriminalização e as ampliações na política sobre o aborto; acreditam que elas se complementam. No cenário uruguaio essa construção discursiva é bem mais frequente, pois foi utilizada para rebater críticas aos projetos de lei em discussão. Para ilustrar o exposto, apresentamos o discurso da deputada Nora Castro (Frente Ampla-Montevidéu):

Em tradução nossa: "Por outro lado, alguns se perguntam por que atuar simultaneamente nos aspectos educacionais e na descriminalização do aborto. Por que não atuar primeiro na educação, avaliar os resultados de um possível plano de cinco anos, por exemplo, e em uma segunda etapa propor estudar e talvez aprovar um projeto desse tipo?

Em primeiro lugar, os efeitos de qualquer programa ou plano educacional são de longo ou médio prazo, e não imediatos. Portanto, as respostas são muito claras. Em minha opinião, são de duas ordens. A primeira é que esta legislação sobre o aborto está em vigor há 64 anos, passando por diferentes governos, alguns com coincidências ideológicas e políticas; mas estamos neste assunto há 64 anos e temos uma prática social sobre a qual existe um diagnóstico consensual que mostra que o efeito pretendido não foi alcançado, pelo menos na letra. Houve tempo para se implementar essas políticas educacionais que agora estão sendo exigidas!" ${ }^{5}$

Outro aspecto a ressaltar é que até os anos 2000 a posição pela educação sexual elou planejamento familiar estava preponderantemente associada nos dois países à ampliação dos direitos reprodutivos, assim como à oposição às políticas de controle populacional. No Brasil, durante as décadas de 1980 e 1990 a posição pela educação sexual elou planejamento familiar foi um dos principais fundamentos dos movimentos feministas e negros para coibir as açóes de esterilizações de mulheres pobres no Nordeste do país, promovidas por organizaçóes internacionais. $\mathrm{O}$ combate a essas açôes resultou no estabelecimento na Câmara de Deputados, em 1992, da Comissão Parlamentar de Inquérito (CPI) das Esterilizaçôes, a qual apontou a motivação higienista e racista dessas ações que ocorreram no Brasil e em outros países da América Latina. Portanto, a demanda por políticas de educação sexual e planejamento familiar passou a ser mobilizada nos discursos para expressar posição contrária ao aborto somente a partir dos anos 2000; nessa circunstância tais políticas são apontadas como alternativas à ampliação dos direitos reprodutivos (Biroli e Miguel, 2016). ${ }^{6}$

A categoria a favor da manutençâo da lei se caracteriza pela posição em defesa da legislação e situaçóes vigentes nos países. Sendo assim, identifica aqueles discursos que apresentam resistências quanto às mudanças na legislaçáo. Nesse sentido, foi empregada pelos(as) parlamentares com distintas conotaçôes.

Por um lado, essa posição foi sustentada para preservar a criminalização do aborto no intuito de impedir ampliaçóes ou regulamentações. No Brasil, precisamente em 92 (de 202) pronunciamentos, por exemplo, tal posição foi utilizada para efetuar oposiçáo ao Projeto de Lei 20/91, de autoria do deputado Eduardo Jorge (PT-SP), cujo objetivo 
era regulamentar a realização do aborto pela rede hospitalar do Sistema Único de Saúde (SUS) nas situaçóes admitidas pela legislação e no contexto de discussão acerca da permissão do aborto de fetos diagnosticados com anencefalia. No Uruguai, em quarenta (do total de 66) discursos, a posição $a$ favor da manutenção da lei foi utilizada para efetuar resistência moderada aos projetos para descriminalizar a interrupção voluntária da gravidez.

Por outro lado, também serviu de suporte para os(as) parlamentares se colocarem contrários às restriçôes, diante de proposiçóes para criminalizar o aborto nas circunstâncias já previstas na lei. No Brasil a defesa da manutenção da legislação com esse propósito foi mobilizada em 48 (de 202) discursos, entre as situações expressivas estão as objeçóes à Proposta de Emenda à Constituição (PEC) 25/1995, de autoria do deputado Severino Cavalcanti (PPB/PE), que tinha por objetivo dar nova redação ao caput do artigo $5^{\circ}$ da Constituição, garantindo definitivamente a inviolabilidade do direito à vida desde a concepção, e ao Estatuto do Nascituro, que dispóe sobre o direito a nascer do ser humano já concebido, tornando a prática do aborto crime hediondo (Miguel, Biroli e Mariano, 2017; Mariano e Silva, 2017).

No Uruguai, após a descriminalizaçáo do aborto, três projetos de lei foram apresentados com o objetivo de propor recuos na legislação aprovada. Assim, os(as) parlamentares que outrora se posicionavam a favor da ampliação do aborto legal, agora se colocam a favor da manutenção da lei, registrando quatro discursos com essa inflexão. Mesmo assim, consideramos importante ter preservado nesse contexto a categoria a favor da ampliação do aborto legal para identificar falas relacionadas à demandas por ampliação da rede de assistência hospitalar e médica e o cumprimento do Decreto do Poder Executivo n. 375/2012, o qual regulamentou a Lei do Aborto e restringiu a objeção de consciência, que se tornou reivindicação de setores conservadores para tornar a legislação, em certa medida, ineficaz, pois profissionais de saúde poderiam se negar a realizar o aborto por razóes morais.

Portanto, a posição a favor da manutenção $d a$ lei não foi necessariamente assumida para expressar oposição à ampliação dos direitos reprodutivos; todavia, na ampla maioria das vezes, foi empregado para preservar a manutenção da criminalização.

Após examinar a composição das posiçôes assumidas nos discursos, pontuar características específicas dos posicionamentos e a comparação entre os países, precisamos analisar o modo como essas posiçóes se distribuem ao longo da série histórica. Os gráficos 1 e 2 abaixo oferecem panorama de acordo com cada legislatura.

\section{Gráfico 1}

Distribuiçáo dos discursos contrários ao aborto, três posiçóes contrárias fundidas: ${ }^{7}$ a favor da ampliaçáo do aborto legal, a favor da manutençáo da lei e pela educaçáo sexual elou planejamento familiar por legislatura no Brasil (1985-2016).

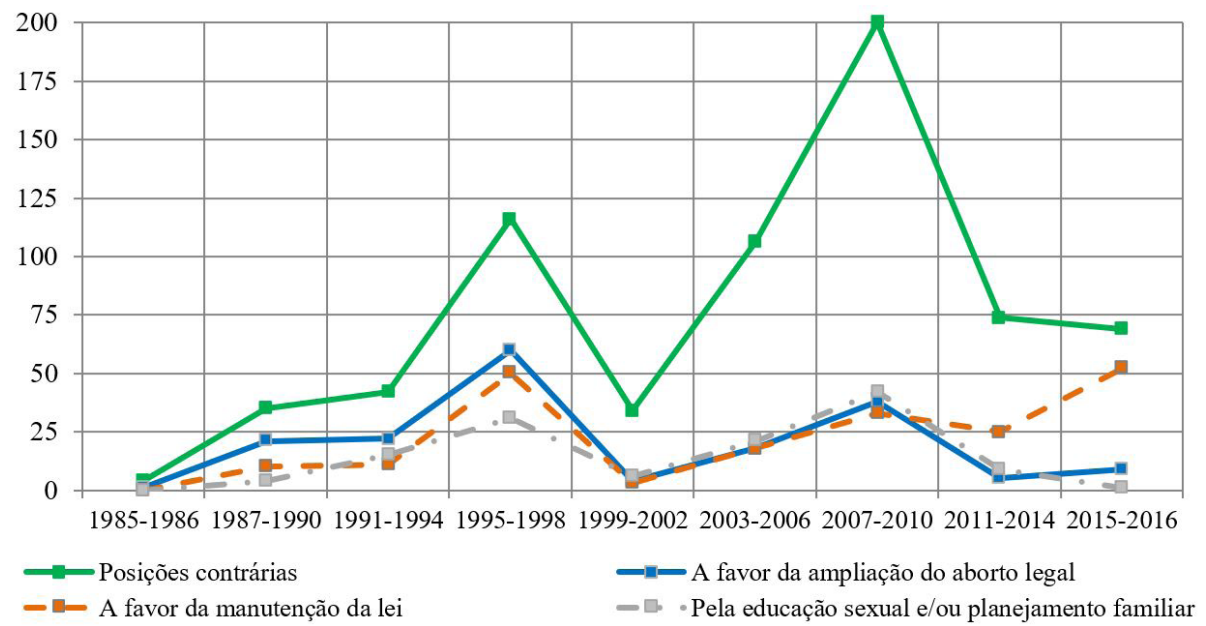

Fonte: Elaboração própria com base nos dados do projeto "Direito ao aborto e os sentidos da maternidade: atores e posiçóes em disputa no Brasil contemporâneo”, financiado pelo edital MCTI/CNPq/SPM-PR/MDA n. 32/2012. 


\section{Gráfico 2}

Distribuição dos discursos contrários ao aborto, três categorias fundidas: a favor da ampliaçáo do aborto legal, a favor da manutençáo da lei e pela educaçáo sexual elou planejamento familiar por legislatura no Uruguai (1985-2016)

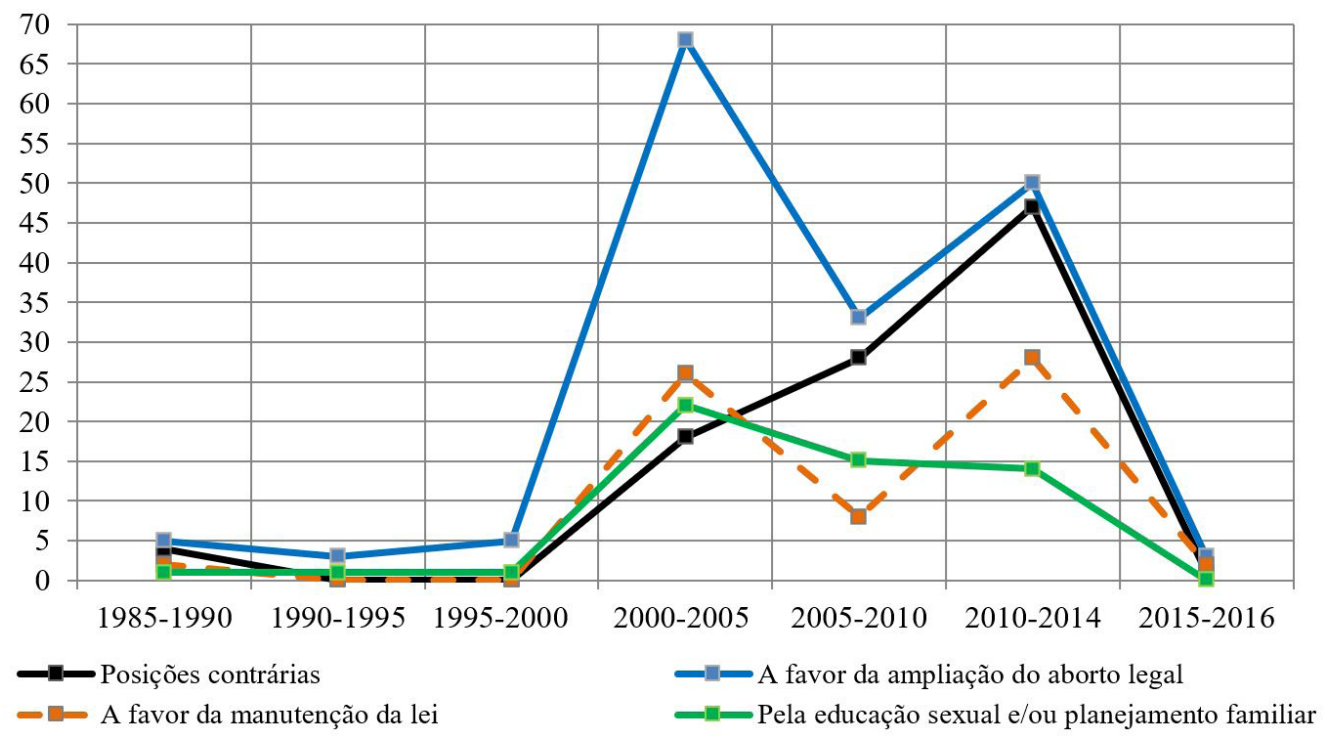

Fonte: Elaboração própria com base nos dados do projeto "Direito ao aborto e os sentidos da maternidade: atores e posiçôes em disputa no Brasil contemporâneo", financiado pelo edital MCTI/CNPq/SPM-PR/MDA n. 32/2012.

Ao observar o gráfico, constatamos que entre os(as) parlamentares do Brasil as posiçóes contrárias ao aborto são preponderantes em todas as legislaturas. De 1985 até a legislatura de 1995-1998 esse predomínio é igualmente verificável, porém há certo equilíbrio, dentro do contexto dos dados entre posiçóes contrárias e favoráveis. Quando estabelecemos a mesma comparação entre as posiçóes a partir da legislatura de 1999-2002, a diferença se torna significativamente desproporcional. Os resultados desta investigação permitem aferir que a explicação para esse cenário converge para o estabelecimento de uma correlação entre a elevação das posiçóes contrárias e regressivas sobre o aborto com a institucionalização e o crescimento das frentes parlamentares confessionais, como a evangélica e a católica, além das frentes contra o aborto na Câmara dos Deputados (Miguel, 2012; Biroli, 2014, 2018; Silva, 2017b). ${ }^{8}$

Essa constatação é consoante à tese de que, no início dos anos 2000, houve maior mobilização de atores e grupos religiosos vinculados a igrejas pentecostais, neopentecostais e católica (sobretudo, a Renovação Carismática) para a inserção na política institucional, especialmente pela incorporação de estratégias políticoeleitorais para eleição de representantes. Além do mais, a partir desse período também foi possível verificar com mais clareza a composição de uma mobilização regular no Poder Legislativo e a construção de um discurso mais unívoco, que pudesse caracterizar a agenda dos(as) deputados(as) remanescentes dos diferentes segmentos do cristianismo (Machado, 2012).

$\mathrm{Na}$ tabela 4 é apresentada a composição de todas as frentes parlamentares sobre o aborto formadas na Câmara dos Deputados do Brasil desde a redemocratização.

De acordo com a antropóloga Lia Zanotta Machado (2017), a organização dos movimentos contrários ao aborto se intensificou no âmbito internacional no final dos anos de 1960, com o intuito de impedir, ainda que sem êxito em muitos casos, a deliberação e a aprovação da descriminalização da interrupção voluntária da gravidez em países da Europa (como Reino Unido, Dinamarca, França, Itália, Holanda, Suécia, entre outros) e nos Estados Unidos. Desde então, o autointitulado Movimento Pró-Vida se institucionalizou (com amplo apoio da cúpula da 
Tabela 4

Frentes parlamentares sobre aborto na Câmara dos Deputados (2003-2019)

\begin{tabular}{|c|c|c|c|c|c|}
\hline Frente & rlamentar & $\begin{array}{l}\text { Defesa da vida - } \\
\text { contra o aborto }\end{array}$ & $\begin{array}{c}\text { Família e apoio } \\
\text { à vida }\end{array}$ & $\begin{array}{c}\text { Contra a } \\
\text { legalizaçáo do } \\
\text { aborto }\end{array}$ & $\begin{array}{c}\text { Defesa da vida e } \\
\text { da família }\end{array}$ \\
\hline \multirow{3}{*}{$\begin{array}{l}52^{\mathrm{a}} \text { legislatura } \\
2003-2006\end{array}$} & Ano de registro & 2005 & \multirow{3}{*}{$\begin{array}{c}\text { Não havia sido } \\
\text { proposta }\end{array}$} & \multirow{3}{*}{$\begin{array}{c}\text { Não havia sido } \\
\text { proposta }\end{array}$} & \multirow{3}{*}{$\begin{array}{c}\text { Não havia sido } \\
\text { proposta }\end{array}$} \\
\hline & Signatários & 193 deputados & & & \\
\hline & Presidida & $\begin{array}{c}\text { Luiz Bassuma } \\
\text { (PT-BA) }\end{array}$ & & & \\
\hline \multirow{3}{*}{$\begin{array}{c}53^{\mathrm{a}} \text { legislatura } \\
2007-2010\end{array}$} & Ano de registro & 2007 & 2007 & 2007 & \multirow{3}{*}{$\begin{array}{c}\text { Não havia sido } \\
\text { proposta }\end{array}$} \\
\hline & Signatários & 202 deputados & 197 deputados & 194 deputados & \\
\hline & Presidida & $\begin{array}{l}\text { Luiz Bassuma } \\
\text { (PT-BA) }\end{array}$ & $\begin{array}{l}\text { Bispo Rodovalho } \\
\text { (PFL-DF) }\end{array}$ & $\begin{array}{l}\text { Leandro Sampaio } \\
\quad(\text { PPS-RJ) }\end{array}$ & \\
\hline \multirow{3}{*}{$\begin{array}{c}54^{\mathrm{a}} \text { legislatura } \\
2011-2014\end{array}$} & Ano de registro & 2011 & 2011 & \multirow{3}{*}{ Náo foi relançada } & \multirow{3}{*}{$\begin{array}{c}\text { Não havia sido } \\
\text { proposta }\end{array}$} \\
\hline & Signatários & 192 deputados & 202 deputados & & \\
\hline & Presidida & $\begin{array}{c}\text { Salvador Zimbaldi } \\
\text { (PMDB-SP) }\end{array}$ & $\begin{array}{l}\text { Fátima Pelaes } \\
\text { (PMDB-AP) }\end{array}$ & & \\
\hline \multirow{3}{*}{$\begin{array}{c}55^{a} \text { legislatura } \\
2015-2019\end{array}$} & Ano de registro & \multirow{3}{*}{ Não foi relançada } & 2015 & \multirow{3}{*}{ Náo foi relançada } & 2015 \\
\hline & Signatários & & 207 deputados & & 236 deputados \\
\hline & Presidida & & $\begin{array}{l}\text { Ronaldo Fonseca } \\
\text { (PRONA-DF) }\end{array}$ & & $\begin{array}{l}\text { Pastor Alan Rick } \\
\text { (PRB-AC) }\end{array}$ \\
\hline
\end{tabular}

Fonte: Elaboração própria com base em Brasil (2020a).

Igreja Católica, especialmente a partir o papado de João Paulo II), por meio de organizações da sociedade civil e pela eleição de representantes políticos de sua agenda. Verificou-se a realização de açóes políticas para reivindicar a preservação e/ou ampliação da criminalização do aborto nos casos permitidos em de cada país, enfatizando o direito e a primazia do embriāo/feto sobre os direitos das mulheres (Ruibal, 2014; Machado, 2017; Mariano e Silva, 2017).

Lia Zanotta Machado (2017) e Naara Luna (2014), com base nos resultados de suas investigaçóes dos discursos parlamentares em comissóes e no plenário da Câmara dos Deputados, respectivamente, argumentam que a mobilizaçáo de setores contrários ao aborto se estruturou a partir de 2004, em reação a ações do Poder Judiciário e Executivo. Em 2004, o ministro Marco Aurélio Mello, do Supremo Tribunal Federal (STF), expediu uma liminar reconhecendo o direito a interrupção da gravidez de fetos diagnosticados com anencefalia; em outubro do mesmo ano, os ministros STF decidiram cassar tal liminar para realizar deliberaçôes e consultas à sociedade civil e aos órgãos técnicos. Em 2012, o
STF descriminalizou o aborto em casos de anencefalia (Diniz e Vélez, 2008).

Em 2005, o presidente Luiz Inácio Lula da Silva encaminhou ao Poder Legislativo a minuta de projeto de lei em favor da descriminalização do aborto. Esse projeto foi resultado das açóes da Secretaria de Políticas para as Mulheres (SPM), órgão do Poder Executivo, em interlocução com os movimentos feministas, e das deliberações da comissão tripartite instalada no Congresso Nacional, por iniciativa da SPM, constituída de membros do Executivo, do Legislativo e da sociedade civil, cujo propósito era revisar a legislação punitiva sobre o aborto (Machado, 2017). Nesse mesmo ano, o Poder Executivo editou a norma técnica, intitulada Atenção humanizada ao abortamento, cujo propósito era retirar a exigência do boletim de ocorrência (BO) e/ou laudo do Instituto Médico Legal (IML) para comprovação da violência sexual (Luna, 2014). Também em 2005, o presidente Lula sancionou, após aprovação no Congresso, a Lei de Biossegurança, a qual autorizou a extração de células-tronco embrionárias de embrióes restantes de reprodução assistida (Emmerick, 2013; Luna, 2014). 
Nesse cenário constrói-se a reação de grupos contrários e a organização das frentes parlamentares sobre o aborto, que ajudam a compreender os dados apresentados sobre as manifestações em plenário. Entre as ações das frentes estão a realização dos Seminários em Defesa da Vida, que acontecem todos os anos desde 2005 na Câmara dos Deputados, reunindo lideranças políticas, religiosas, da sociedade civil e ativistas pró-vida (Machado, 2017). As frentes também auxiliaram na organização do Encontro Brasileiro de Legisladores e Governantes pela Vida, que ocorrem com certa regularidade desde 2007 no âmbito estadual, nacional, continental (América Latina) e mundial, ressaltando o aspecto transnacional da mobilização contra o aborto identificada por Alba Ruibal (2014).

Conforme sustentam Rulian Emmerick (2013) e Naara Luna (2014), a interlocução entre representantes políticos e a sociedade civil resultou na criação, em 2006, do Movimento Nacional Brasil sem Aborto, cuja finalidade é promover maior coordenação nas ações e mobilizar a população contra proposiçôes políticas para regulamentar e/ou descriminalizar o aborto. Exemplo dessa articulação foi a realização da I Marcha em Defesa da Vida contra a legalização do aborto, em 2007, na cidade de Brasília (DF), a qual ocorreu em quase todos os anos subsequentes a sua criação. Desse modo, é verificável a mobilização estruturada de oposição ao aborto na Câmara dos Deputados do Brasil, não sendo possível diagnosticar composição parlamentar similar no âmbito da ampliação dos direitos reprodutivos das mulheres.

No legislativo uruguaio os dados revelam um contexto diferente do identificado na Câmara dos Deputados do Brasil, posto que a posição a favor da ampliação do aborto legal é superior em todas as legislaturas, com certo equilíbrio na diferença numérica, em comparação às posições contrárias. É importante levar em consideração que essa diferença permanece constante na série histórica, mesmo diante do avanço, nas duas últimas décadas, de clivagens cristãs conservadoras na América Latina. Aliás, vale sublinhar nesta comparação que enquanto no Brasil, entre 2003 e 2010, registraram-se os maiores índices de reaçôes contrárias e regressivas em plenário, no Uruguai em período similar, de 2002 a 2010, foram identificados os maiores índices de posiçôes favoráveis em relação às contrárias, além de três projetos de lei sobre a descriminalização do aborto aprovados na Câmara de Representantes. Em grande medida, esse quadro é explicado pelo processo de reivindicação e mobilização em torno dos direitos reprodutivos, engendrado pelos movimentos feministas e também (em interlocução) pela Frente Ampla, coalizão de partidos políticos de esquerda no Uruguai.

No período entre 1985 e 1999 a atuação dos movimentos feministas consistiu em construir uma agenda consensual entre organizaçôes, representantes políticos e sociedade (Johnson, Rocha e Schenck, 2015). Assim, sua mobilização não se direcionou para fomentar a inserção da descriminalização no debate parlamentar, pelo menos em esferas de discussão ampla e/ou tomada de decisão, como a ordem do dia, pois o assunto foi deliberado em comissóes temáticas no período. É plausível estimar que razóes estratégicas tenham motivado essa atuação, especialmente pelo fato de o Partido Nacional, principal opositor da agenda, deter relevante influência no Poder Legislativo nesse período. ${ }^{9}$

Nos anos 2000 os movimentos já haviam construído um discurso consolidado, integrando número significativo de organizações de mulheres. Além disso, a demanda em torno do aborto, em virtude dos problemas de saúde pública devido a sua realização em clínicas clandestinas e sua relação com a elevaçấo da mortalidade materna, foi capaz de ampliar a base de apoio em diferentes setores $\mathrm{da}$ sociedade civil, como a Coordinación Nacional de Organizaciones Sociales por la Defensa de la Salud Reproductiva, integrada pelo Plenario Intersindical de Trabajadores - Convención Nacional de Trabajadores (PIT-CNT), os movimentos pela diversidade sexual, as organizaçôes religiosas (como a Igreja Metodista), as redes de jovens e os principais hospitais, instituições e organizaçóes de saúde do Uruguai (Johnson et al., 2015; Rostagnol, 2009). Conforme sustentam Lilián Abracinskas e Alejandra Gómez (Abracinskas e Gómez, 2007), a agenda extrapolou o círculo de discussóes exclusivamente construído pelos movimentos feministas para se tornar, até certo ponto, reivindicação cidadã. Por exemplo, o levantamento realizado por Lucía Selios (2007) indica que as pesquisas de opinião realizadas entre 2001 e 2004 apontavam que 63\% da 
população uruguaia era a favor da descriminalização do aborto. A ampla adesão social forneceu respaldo para os movimentos feministas, junto aos demais, para participar da discussão e elaboração dos projetos de lei apreciados em plenário e das mobilizações em prol de sua aprovação.

Por sua vez, a Frente Ampla é a principal agremiação do sistema partidário uruguaio a defender a descriminalização do aborto. Na Câmara de Representantes os(as) parlamentares dessa coalizão partidária proferiram 158 discursos entre 1985 e 2016, destes, 130 pronunciamentos se posicionaram a favor da ampliação do aborto legal. Esse número representa 78\% dos 167 discursos enquadrados nessa posição em toda a pesquisa, logo, a ampla maioria das falas favoráveis a descriminalização do aborto. É importante ressaltar que 155 discursos (do total de 158) dos(as) parlamentares da Frente Ampla foram proferidos somente a partir de 1998. Não significa dizer que até esse ano a atuação era discreta nessa agenda, tal informação apenas constata que seu peso político até então era periférico e sua inserção no cenário político aconteceu de modo gradual após a redemocratização.

Essa constatação permite compreender a quantidade de posiçóes a favor da ampliação do aborto legal no Uruguai. Além do mais, permite associar a inscrição recorrente da descriminalização do aborto na agenda parlamentar a partir dos anos 2000 e a aprovaçáo de três projetos de lei (2002, 2008 e 2012) na Câmara de Representantes, com a atuação dos movimentos feministas e o crescimento da Frente Ampla no legislativo no mesmo período.

Precisamos notar igualmente que as manifestações contrárias empreendem uma trajetória ascendente entre 2002 e 2012, cuja resposta repousa em dois pontos de reflexão. Por um lado, o aumento dessas reaçôes contra o aborto em plenário ocorre de acordo com a previsibilidade de aprovação da descriminalização do aborto nas esferas políticas. Em 2002 há menor número de pronunciamentos entre os três anos de deliberação de projetos de lei relacionados à matéria; embora tenha sido aprovado na Câmara de Representantes, o projeto de lei 3.107/1993 foi vetado no Senado. Já em 2008 o PL 536/2006 foi aprovado em ambas as casas legislativas, porém o presidente Tabaré Vazquéz já havia antecipado seu veto à proposição (Rostagnol, 2009). Em 2012 havia condições razoavelmente favoráveis à aprovação do PL 567/2011 nos poderes Legislativo e Executivo, por esse motivo é plausível estimar as razóes para nesse ano ter sido registrado o maior número de discursos contrários. Contudo, é preciso identificar também o crescimento político-eleitoral de vertentes conservadoras, sobretudo ligadas ao Partido Nacional, como já exposto, tradicionalmente oposto à agenda dos direitos reprodutivos. De fato, esse fenômeno é menor no Uruguai em comparação ao Brasil, todavia é possível verificar uma relativa ascendência de posiçóes conservadoras, cuja consolidação ou enfraquecimento pode ser constatado em discussóes sobre o tema nas próximas legislaturas.

\section{Argumentos e posiçóes}

As posiçóes assumidas em cada discurso foram sustentadas por argumentos. Por se tratar de um tema complexo em que estão imbricadas questôes morais, religiosas, liberdades individuais, saúde pública, entre outras, os(as) parlamentares se posicionaram por meio de um leque variado de argumentos. A pesquisa identificou os argumentos mais recorrentes e os transformou em categorias. A partir disso, tornou-se possível construir panoramas quantitativos e qualitativos sobre o modo como esses argumentos foram mobilizados.

Nesta seção, pretendemos demonstrar a existência de alguns padróes presentes nos pronunciamentos dos(as) deputados(as) de ambos os países. Quer dizer, determinadas posiçóes elaboradas regularmente com base em um conjunto razoavelmente definido de argumentos. A identificação da combinação frequente entre posiçóes e argumentos permite a classificação dos pronunciamentos e a construção de matrizes discursivas, assim como o apontamento dos desvios nesses padróes. Para isso, vamos analisar as tabelas 5 e 6 e apontar quais argumentos foram empregados com maior frequência em cada posição, assim como aqueles empregados como base de sustentação da fala, isto é, classificados como argumento principal.

Em cada discurso era permitido assinalar os argumentos mobilizados pelo(a) parlamentar, no 
entanto, era necessário identificar um como o principal, a sustentação da fala. Na tabela 6 demonstramos os índices aferidos em cada país.

Nos subitens a seguir pretendemos discutir as categorias em que é inviável estabelecer um padrão definido entre as variáveis posição e argumento. Isso porque, ao analisar a tabela 6 , vamos perceber que quase todos os argumentos foram empregados na assunção delas. Mesmo assim, há diferenças importantes nos tipos de associaçôes dessas posiçôes com os argumentos.

A favor da manutenção da lei, pela educação
sexual elou planejamento familiar

A posição a favor da manutenção da lei, como dito antes, não necessariamente representa oposição

Tabela 5

Distribuição dos discursos de acordo com as posiçóes e os argumentos no Brasil (BR) e no Uruguai (UY) (1985-2016)

\begin{tabular}{|c|c|c|c|c|c|c|c|c|c|c|c|c|c|c|}
\hline \multirow[b]{2}{*}{ Argumento $\downarrow$ País $\rightarrow$} & \multicolumn{2}{|c|}{$\begin{array}{c}\text { A favor da } \\
\text { ampliaçáo } \\
\text { do aborto } \\
\text { legal }\end{array}$} & \multicolumn{2}{|c|}{$\begin{array}{l}\text { A favor da } \\
\text { manutençáo } \\
\text { da lei }\end{array}$} & \multicolumn{2}{|c|}{$\begin{array}{l}\text { A favor da } \\
\text { restriçáo } \\
\text { do aborto } \\
\text { legal }\end{array}$} & \multicolumn{2}{|c|}{$\begin{array}{c}\text { Contra } \\
\text { o aborto } \\
\text { (genérico) }\end{array}$} & \multicolumn{2}{|c|}{$\begin{array}{l}\text { Por novas } \\
\text { medidas } \\
\text { punitivas } \\
\text { e/ou de } \\
\text { controle } \\
\end{array}$} & \multicolumn{2}{|c|}{$\begin{array}{c}\text { Pela } \\
\text { educaçáo } \\
\text { sexual e/ou } \\
\text { planejamento } \\
\text { familiar } \\
\end{array}$} & \multicolumn{2}{|c|}{ Total } \\
\hline & BR & UY & BR & UY & BR & UY & BR & UY & BR & UY & BR & UY & BR & UY \\
\hline Argumentos religiosos & 3 & 8 & 76 & 5 & 105 & 0 & 167 & 19 & 42 & 1 & 30 & 5 & 423 & 38 \\
\hline Argumentos científicos & 7 & 30 & 20 & 11 & 35 & 1 & 44 & 25 & 22 & 1 & 15 & 11 & 143 & 79 \\
\hline $\begin{array}{l}\text { Aborto é questáo de } \\
\text { saúde pública }\end{array}$ & 114 & 103 & 27 & 3 & 13 & 0 & 26 & 1 & 20 & 0 & 65 & 18 & 265 & 125 \\
\hline Liberdade individual & 78 & 72 & 10 & 1 & 0 & 0 & 0 & 0 & 1 & 0 & 14 & 10 & 103 & 83 \\
\hline $\begin{array}{l}\text { Controle da mulher } \\
\text { sobre o próprio corpo }\end{array}$ & 17 & 51 & 4 & 0 & 0 & 0 & 0 & 0 & 0 & 0 & 3 & 7 & 24 & 58 \\
\hline Argumentos jurídicos & 33 & 65 & 96 & 36 & 73 & 1 & 94 & 48 & 54 & 1 & 37 & 22 & 387 & 173 \\
\hline Argumentos econômicos & 5 & 7 & 7 & 2 & 10 & 0 & 4 & 0 & 8 & 0 & 9 & 0 & 43 & 9 \\
\hline $\begin{array}{l}\text { Inviolabilidade do } \\
\text { direito à vida }\end{array}$ & 1 & 5 & 127 & 34 & 155 & 1 & 292 & 69 & 105 & 1 & 61 & 22 & 741 & 132 \\
\hline Injustiça social & 70 & 67 & 15 & 3 & 4 & 0 & 4 & 1 & 3 & 0 & 33 & 8 & 129 & 79 \\
\hline $\begin{array}{l}\text { Argumentos morais } \\
\text { (não explicitamente } \\
\text { religiosos) }\end{array}$ & 6 & 6 & 64 & 35 & 87 & 0 & 143 & 65 & 45 & 1 & 35 & 28 & 380 & 135 \\
\hline $\begin{array}{l}\text { Argumentos vinculados } \\
\text { à opinião pública }\end{array}$ & 14 & 8 & 45 & 7 & 63 & 0 & 84 & 10 & 37 & 0 & 35 & 2 & 278 & 27 \\
\hline $\begin{array}{l}\text { Controle da natalidade } \\
\text { como estratégia } \\
\text { imperialista }\end{array}$ & 1 & 2 & 16 & 4 & 18 & 0 & 29 & 4 & 18 & 0 & 8 & 4 & 90 & 14 \\
\hline Laicidade do Estado & 26 & 28 & 4 & 3 & 0 & 0 & 0 & 0 & 0 & 0 & 6 & 2 & 36 & 33 \\
\hline Outros & 26 & 55 & 86 & 48 & 51 & 0 & 109 & 53 & 52 & 1 & 26 & 36 & 351 & 192 \\
\hline Nenhum & 10 & 2 & 11 & 4 & 3 & 0 & 26 & 1 & 10 & 0 & 4 & 1 & 64 & 8 \\
\hline Total & 412 & 509 & 608 & 196 & 617 & 3 & 1.022 & 296 & 417 & 5 & 381 & 176 & 3.457 & 1.185 \\
\hline
\end{tabular}

Fonte: Elaboração própria com base nos dados do projeto "Direito ao aborto e os sentidos da maternidade: atores e posiçóes em disputa no Brasil contemporâneo", financiado pelo edital MCTI/CNPq/SPM-PR/MDA n. 32/2012. Observação: Era possível assinalar, em cada discurso, até duas posiçóes. Não havia limites para os argumentos, embora nenhum pronunciamento tenha empregado mais de sete. 
Tabela 6

Distribuiçáo dos discursos de acordo com o argumento principal assumido pelos(as) parlamentares nos legislativos brasileiro e uruguaio (1985-2016)

\begin{tabular}{|c|c|c|c|c|}
\hline \multirow{2}{*}{$\begin{array}{c}\text { País } \rightarrow \\
\text { Argumento principal } \downarrow\end{array}$} & \multicolumn{2}{|c|}{ BRASIL } & \multicolumn{2}{|c|}{ URUGUAI } \\
\hline & Q. & $\%$ & Q. & $\%$ \\
\hline Argumentos religiosos & 129 & $12 \%$ & 7 & $2,1 \%$ \\
\hline Argumentos científicos & 20 & $1,85 \%$ & 12 & $3,6 \%$ \\
\hline Aborto é questão de saúde pública & 111 & $10,3 \%$ & 61 & $18,1 \%$ \\
\hline Liberdade individual & 38 & $3,55 \%$ & 17 & $5 \%$ \\
\hline Controle da mulher sobre o próprio corpo & 5 & $0,5 \%$ & 6 & $1,8 \%$ \\
\hline Argumentos jurídicos & 71 & $6,6 \%$ & 26 & $7,7 \%$ \\
\hline Argumentos econômicos & 3 & $0,3 \%$ & 3 & $0,9 \%$ \\
\hline Inviolabilidade do direito à vida & 328 & $30,5 \%$ & 53 & $15,7 \%$ \\
\hline Injustiça social & 15 & $1,4 \%$ & 10 & $3 \%$ \\
\hline Argumentos morais (não explicitamente religiosos) & 53 & $4,9 \%$ & 25 & $7,4 \%$ \\
\hline Argumentos vinculados à opinião pública & 45 & $4,2 \%$ & 7 & $2,1 \%$ \\
\hline $\begin{array}{l}\text { Aborto/controle da natalidade como estratégia } \\
\text { imperialista }\end{array}$ & 20 & $1,85 \%$ & 0 & $0 \%$ \\
\hline Laicidade do Estado & 8 & $0,75 \%$ & 18 & $5,3 \%$ \\
\hline Outros* & 168 & $15,6 \%$ & 84 & $25 \%$ \\
\hline Nenhum $^{\dagger}$ & 64 & $6 \%$ & 8 & $2,4 \%$ \\
\hline Total & 1.078 & $100 \%$ & 337 & $100 \%$ \\
\hline \multicolumn{5}{|c|}{ 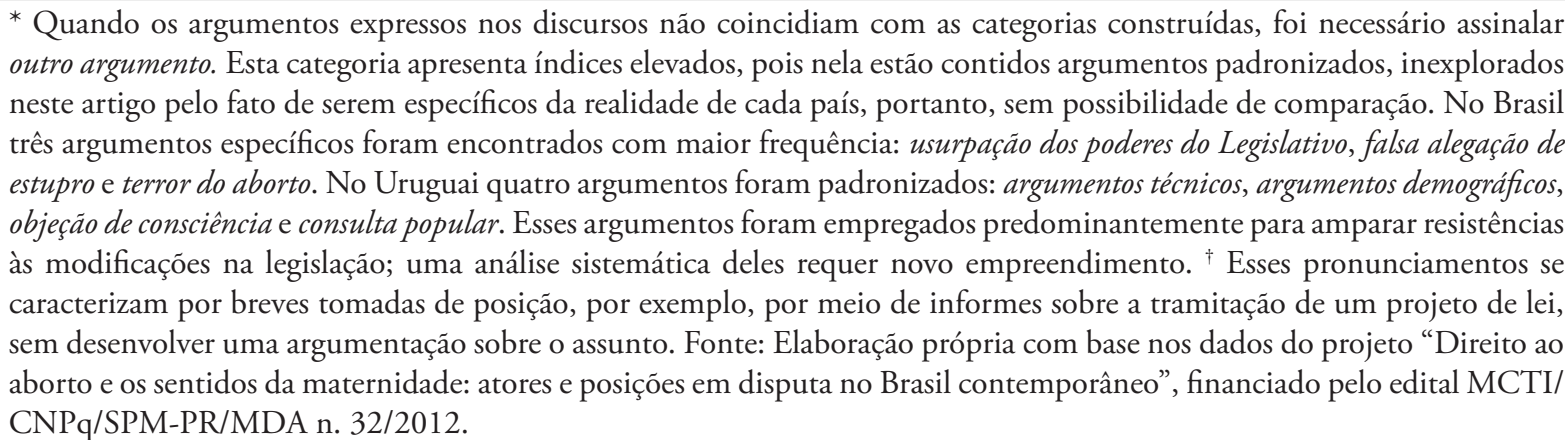 } \\
\hline
\end{tabular}

ao aborto, pois em alguns casos pode indicar o desejo de impedir recuos na legislação vigente. Contudo, tanto no Brasil como no Uruguai, os argumentos mais citados com ela foram os mesmos utilizados naquelas posiçóes contrárias ao aborto: inviolabilidade do direito à vida; argumentos morais (não explicitamente religiosos) e argumentos jurídicos. No legislativo brasileiro podemos acrescentar: argumentos religiosos e argumentos vinculados à opinião pública. Como mencionado, a inclinação no uso dessa posição é mais pendente à manutenção da criminalização do que em relação a recuos regressivos na legislação.

A posição pela educação sexual elou planejamento familiar é o caso mais paradigmático em referência a seu aspecto difuso. Em ambos os países, os argumentos que fundamentaram essa posição, na maior parte das vezes, são os mesmos atrelados as posiçóes a favor e contra ao aborto, inclusive com proximidade no número de citações. Não obstante, sua junção com argumentos vinculados a posições contrárias ainda é superior, ao observar a tabela 6 percebemos que essa característica é mais latente no Uruguai que no Brasil.

\section{A favor da ampliação do aborto legal}

Esta posição foi assumida em 167 discursos na Câmara de Representantes do Uruguai e em 178 na 
Câmara de Deputados do Brasil. De todos podemos destacar cinco como os mais empregados nas duas casas legislativa, pela ordem os mais citados: aborto é questão de saúde pública, assinalado quando o discurso sinalizava os riscos à saúde e à vida da mulher decorrentes do aborto clandestino praticado em condiçōes sanitárias insalubres; liberdade individual, quando salientava o direito da mulher decidir sobre o aborto; injustiça social, sempre que ponderava as desigualdades de condiçóes econômicas entre mulheres pobres e ricas com relação a recorrer ao aborto ilegal realizado de forma segura em clínicas privadas; controle da mulher sobre o próprio corpo, quando pontuava a autonomia da mulher a decidir sobre seu corpo; laicidade do Estado, sempre que o discurso demarcava que o Estado era laico, sinalizando que argumentos baseados em convicçóes religiosas não eram legítimos no debate em questão. Os dois últimos argumentos não possuem o mesmo volume de citaçóes que os demais, mas proporcionalmente em quase todas as vezes que os(as) parlamentares dos dois países os utilizaram foi para se posicionar a favor da ampliação do aborto legal, por isso sua inclusão nessa lista.

O desvio mais expressivo nesse padrão é encontrado no Brasil no uso do argumento aborto é questão de saúde pública. Uma vez que essa categoria foi empregada em 53 discursos (do total de 199 discursos em que foi utilizada) com posiçôes contrárias ao aborto. Ao desagregar os dados percebemos que cinquenta desses discursos (do total de 53) foram pronunciados por parlamentares do sexo masculino. Em boa parte desses casos houve, de certo modo, o reconhecimento da existência do fenômeno, isto é, a mortalidade materna provocada por abortos realizados em condiçôes insalubres, porém a solução apresentada perpassou por maiores instrumentos de repressão a quem procura e realiza abortos ilegais. Para ilustrar, reproduzimos a fala do deputado Marcos Montes (PFL/DEM-MG):

Defendo a inclusão de normas de ordem penal e civil no Estatuto da Criança e do Adolescente para proteção dos nascituros e de suas mães. (...) Por esse motivo, penso que, por uma questão simétrica, o comércio ilegal de medicamentos abortivos deve ser combatido com o mesmo rigor com que se combate o tráfico de drogas. Da mesma forma, devem ser punidos aqueles que usarem qualquer artifício para induzir à prática abortiva ou forçá-la.

(...) Esse é um problema de saúde pública e de polícia e ocorre no mais elevado grau de perversidade, pois acontece no seio de milhares de famílias, trazendo às mulheres danos muitas vezes irreparáveis (...). (Brasil, Diários da Câmara dos Deputados, 30 nov. 2010, p. 47.971)

Nos gráficos 3 e 4 constam a distribuição desses argumentos que serviram de suporte à fundamentação da posição a favor da ampliação do aborto legal nas legislaturas analisadas.

Os gráficos 3 e 4 demonstram que no Uruguai os argumentos a favor da ampliaçấo do aborto legal mantêm uma estabilidade no decurso da série histórica, diminuindo e aumentando proporcionalmente de acordo com os períodos em que o tema esteve na agenda da ordem do dia, sem grandes variaçóes na escala entre os argumentos mais e menos citados.

É possível verificar ainda que essa posiçâo foi sustentada principalmente com base nos problemas de saúde pública, autonomia individual e rejeiçâo à ingerência religiosa no debate. Esse panorama pode ser avaliado como reflexo da consolidaçáo do regime laico no Uruguai, cujas raízes são derivadas de tensōes e processos remanescentes do século XIX e início do século XX, por conseguinte, preservadas no contexto contemporâneo (Guigou, 2011). Não obstante, conforme argumenta Roberto Blancarte (2008), a laicidade do Estado não se desenvolve sem que estruturas político-sociais reivindiquem a preservação de seus princípios como elementos regentes da democracia. No Uruguai, como já destacado, a coalizão entre os partidos de esquerda que formam a Frente Ampla e os movimentos feministas inseriu a discussão sobre o aborto na esfera legislativa, mais que isso, desempenhou o papel de situar a laicidade do Estado no centro da deliberaçáo.

O impacto que a Frente Ampla promoveu no sistema bipartidário uruguaio náo se resume somente à conquista de cargos eletivos como também pela redefinição dos papéis das forças que compóem esse 


\section{Gráfico 3}

Distribuiçáo dos argumentos mobilizados com a posiçáo a favor da ampliaçáo do aborto legal por legislatura no Brasil (1985-2016)
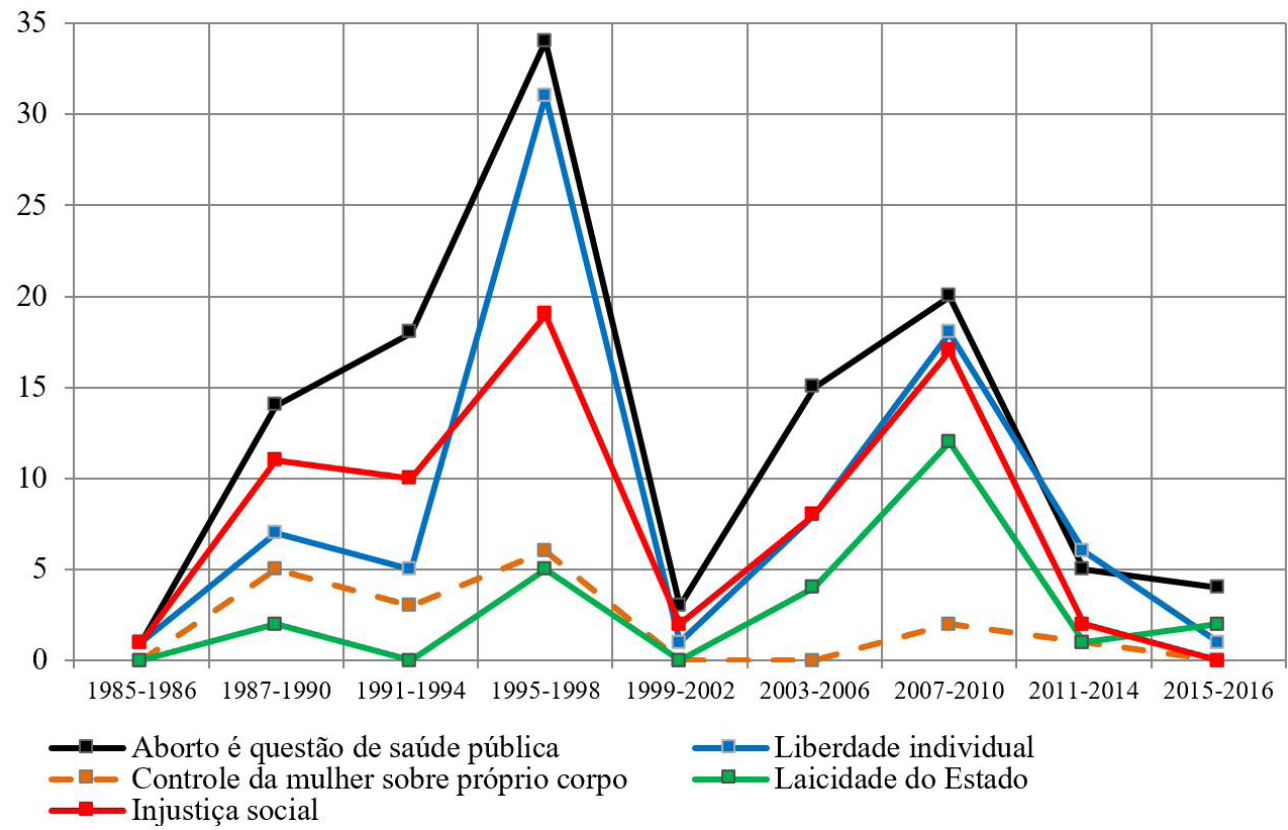

Fonte: Elaboração própria com base nos dados do projeto "Direito ao aborto e os sentidos da maternidade: atores e posiçôes em disputa no Brasil contemporâneo”, financiado pelo edital MCTI/CNPq/SPM-PR/MDA n. 32/2012.

\section{Gráfico 4}

Distribuição dos argumentos mobilizados com a posiçáo a favor da ampliaçáo do aborto legal por legislatura no Uruguai (1985-2016)

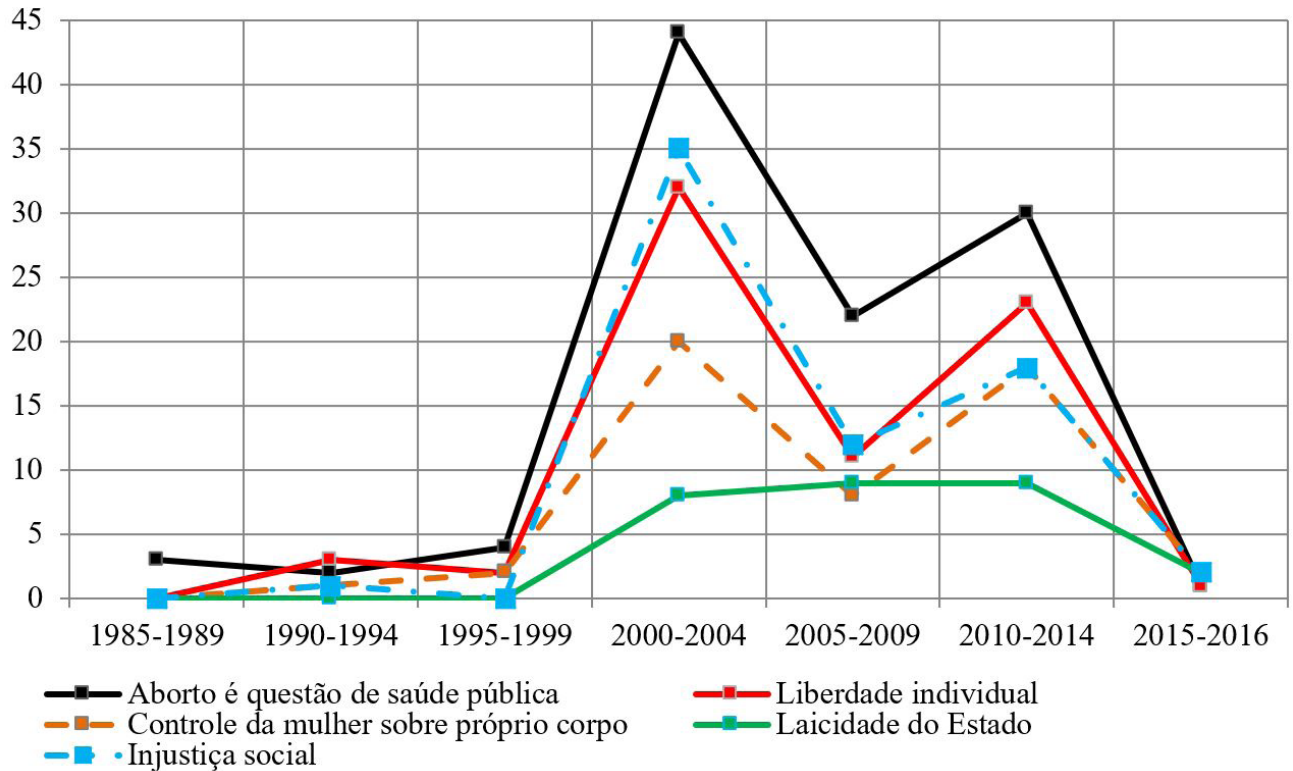

Fonte: Elaboração própria com base nos dados do projeto "Direito ao aborto e os sentidos da maternidade: atores e posiçóes em disputa no Brasil contemporâneo”, financiado pelo edital MCTI/CNPq/SPM-PR/MDA n. 32/2012. 
sistema. Visto que os partidos tradicionais, Nacional e Colorado, desde a redemocratização até 2005 se revezaram no Poder Executivo e se empenharam nesse período em implementar reformas neoliberais. Assim, a Frente Ampla logrou êxito ao se apresentar como alternativa eleitoral a tais partidos e suas propostas, justamente por defender os valores que eram os alicerces da cultura política dos uruguaios, como a defesa de posiçôes estatistas e distributivas e a laicidade do Estado (Lanzaro, 2003; Htun, 2003). Com isso, foi situado em espectro ideológico outrora ocupado pelo Partido Colorado.

Por seu turno, a laicidade do Estado nessa discussão foi mobilizada pelos movimentos feministas para efetuar oposição ao ativismo de grupos contrários e religiosos, a destacar as declaraçóes públicas de Monsenhor Cotugno, principal liderança católica do Uruguai entre 1998 e 2014, as quais tiveram o objetivo de pressionar o Poder Executivo e os parlamentares para vetar a descriminalizaçáo. Não obstante, para os movimentos feministas, a laicidade também foi central na reivindicação de que as mulheres que recorriam ao aborto eram sujeitas de direito, cuja liberdade para decidir pela interrupção da gravidez estava sendo violada. Assim, a descriminalização do aborto foi estruturada preponderantemente com base na ideia de autonomia, autodeterminação individual e liberdade de consciência das mulheres, princípios fundamentais da laicidade do Estado (Johnson, Rocha e, 2015).

No Brasil também podemos notar a ausência de variaçóes significativas nos três argumentos mais citados: aborto é uma questão de saúde pública, liberdade individual e injustiça social. A variação mais expressiva no caso brasileiro está concentrada no argumento controle da mulher sobre o próprio corpo, que praticamente não é mencionado nos pronunciamentos a partir da legislatura de 1995 a 1999. Por outro lado, o argumento pela laicidade do Estado passou a ser evocado nos discursos, sobretudo entre 2007 e 2010, período em que a mobilização religiosa em torno do aborto se institucionalizou na Câmara dos Deputados por meio das frentes parlamentares (Biroli, 2018; Biroli e Miguel, 2016).

Os pronunciamentos efetuados no âmbito da ampliação dos direitos reprodutivos no Brasil, sobretudo a partir dos anos 2000, assumem uma característica mais reativa, no que tange a ingerência religiosa sobre o assunto e a preservação e regulamentação do direito adquirido, por meio da efetivação do aborto em casos de risco de vida da gestante, estupro e anencefalia (Biroli e Miguel, 2016). Os dados demonstram também a primazia de alguns tipos de formulação argumentativa que é, conforme Leila Barsted (2009), consoante à forma preponderante de enquadramento do fenômeno pelos movimentos feministas, ou seja, a ênfase nos problemas de saúde pública, como a mortalidade materna, consequência do aborto realizado em condiçóes insalubres, e em menor proporção sua defesa enquanto direito individual no campo da sexualidade e da autodeterminação.

\section{A favor da restrição do aborto legal, contra o aborto (genérico) e por novas medidas punitivas el ou controle}

Nos dois países três argumentos foram recorrentes para sustentar posiçóes com esses conteúdos, são eles: inviolabilidade do direito à vida, assinalada em situaçóes em que o pronunciamento pontuava a vida humana como valor absoluto a ser protegido pelo Estado; argumentos morais (não explicitamente religiosos), empregado quando o discurso afirmava que a interrupção voluntária da gravidez era um valor impróprio e nocivo à estabilidade de preceitos fundamentais à sociedade, contudo sem vincular os argumentos a questóes religiosas; argumentos religiosos, sempre que havia menção a alguma religião (instituições, ensinamentos, dogmas ou líderes) como base da manifestação da fala.

O desvio nesse padrão é registrado no legislativo uruguaio e tem relação ao emprego de argumentos religiosos. Visto que em $21,5 \%$ das falas (oito do total de 38 citaçóes) esse argumento serviu para sustentar posição favorável ao aborto. $\mathrm{Na}$ maioria dos casos os(as) parlamentares que se pronunciaram dessa forma evocaram questóes teológicas e reflexóes de líderes religiosos para atestar que, mesmo de acordo com o pensamento religioso da Igreja Católica, a criminalização do aborto era um ato injusto. Como exemplo, selecionamos parte da fala do deputado José Bayardi (FA-Montevidéu), que realizou a leitura das 
reflexôes do padre Luis Pérez Aguirre, líder católico do Uruguai e ativista pela descriminalização do aborto:

Em tradução nossa: "Dizia Luiz Pérez Aguirre: 'O aborto é e parece querer continuar sendo uma teimosa e trágica realidade social'. (...) 'A mortalidade por aborto afeta as mulheres pobres porque elas só têm acesso econômico ao aborto clandestino, sem as mínimas condições sanitárias. É claro que são as mulheres pobres que morrem em abortos clandestinos. Enquanto não realizarmos uma análise séria das causas e das condiçóes socioeconômicas e culturais do aborto, enquanto não iniciarmos um processo responsável de ajuste social obrigatório para eliminá-las, todo julgamento e punição das supostas culpadas nada será mais que uma justiça moralista que lava suas mãos e consciência. Se formos realistas, devemos aceitar a evidência de que a realidade não está de acordo com a justiça e, portanto, não é possível dar respostas morais eficazes únicas e iguais para todos os casos"'. (Uruguay, Diario de Sesiones, 10 dez. 2002, p. 55) ${ }^{10}$

Na Câmara dos Deputados do Brasil, outros quatro argumentos apresentam significativo volume de citações ao lado de posiçóes contrárias, ainda que inferiores àqueles mais mobilizados. Primeiro, argumentos vinculados à opinião pública, com o intuito de aludir, por exemplo, "que a população brasileira era contra o aborto”. Lia Zanotta Machado (2017), sustenta que essa narrativa religiosa almeja construir a ideia de que a condenação do aborto é legítima pelo fato de a maioria da população brasileira ser cristá, logo, todos(as) partilhariam dessa premissa, desconsiderando diferentes visões entre as instituiçôes cristãs e a própria percepção dos(as) fiéis sobre o assunto. Depois vieram estes três argumentos: argumentos jurídicos, sempre que havia referência à Constituição ou ao Código Penal; argumentos cientificos, assinalado nas situações em que o discurso se amparava em estudos científicos para afirmar que a vida começa desde a concepção ou para desconstruir essa informação; aborto/controle da natalidade como estratégia imperialista, registrado quando a fala indicava influência de países desenvolvidos na descriminalização do aborto como estratégia para conter o crescimento populacional dos países periféricos. É importante verificar que há sensível variação nesse padrão em virtude de argumentos vinculados à opiniāo pública, jurídicos e científicos serem empregados algumas vezes para sustentar a posição a favor da ampliação do aborto legal.

No Uruguai as categorias argumentos vinculados à opinião pública, argumentos jurídicos, argumentos cientificos e aborto/controle da natalidade como estratégia imperialista não podem ser enquadrados em uma escala de posições contrárias ao aborto. $\mathrm{Na}$ verdade, ao observar os índices de citaçóes desses argumentos, percebemos a impossibilidade de classificar um padrão, pois todos foram empregados de modo equilibrado com as posiçóes a favor e contra o aborto, embora com sensível vantagem às favoráveis. Os gráficos 5 e 6 apresentam a distribuição dos argumentos mobilizados para sustentar posiçóes contrárias ao aborto ao longo da série histórica estudada.

Ao analisar os dados, é possível notar uma tendência à modificação no modo de enquadramento dos argumentos nesse espectro do debate. Os discursos são construídos com fundamentações cada vez menos explicitamente religiosas, embora permaneçam fundados em princípios e crenças. Esse fenômeno é caracterizado por Juan Marco Vaggione (2009, 2012) como secularismo estratégico, uma vez que há uma mudança sensível na forma de argumentação em temas com impacto em preceitos morais e religiosos, portanto, ocorre o deslocamento das elaboraçóes convencionais, como "a vontade de Deus" ou "está na bíblia", para a utilização de outros sistemas de referência, sobretudo baseados em pressupostos científicos e jurídicos, para afirmar o direito à vida desde a concepçâo (Luna, 2010; Miguel et al., 2017).

Esse fenômeno não é algo recente, pode ser datado pelo menos desde a década de 1960, quando passou a ser incorporado de modo mais regular pelos chamados movimentos recristianizadores, entre eles o Movimento Pró-Vida. Essa transfiguração discursiva reflete uma tendência estratégica cada vez mais constante na atuação das forças religiosas em temas de forte apelo moral e/ou religioso. Por exemplo, a pesquisadora Maria José Rosado Nunes (2012) demonstrou a utilização de argumentos científicos como fonte de legitimação à oposição ao aborto 


\section{Gráfico 5}

Distribuiçáo dos argumentos mobilizados com posiçóes contrárias ao aborto por legislatura no Brasil (1985-2016)

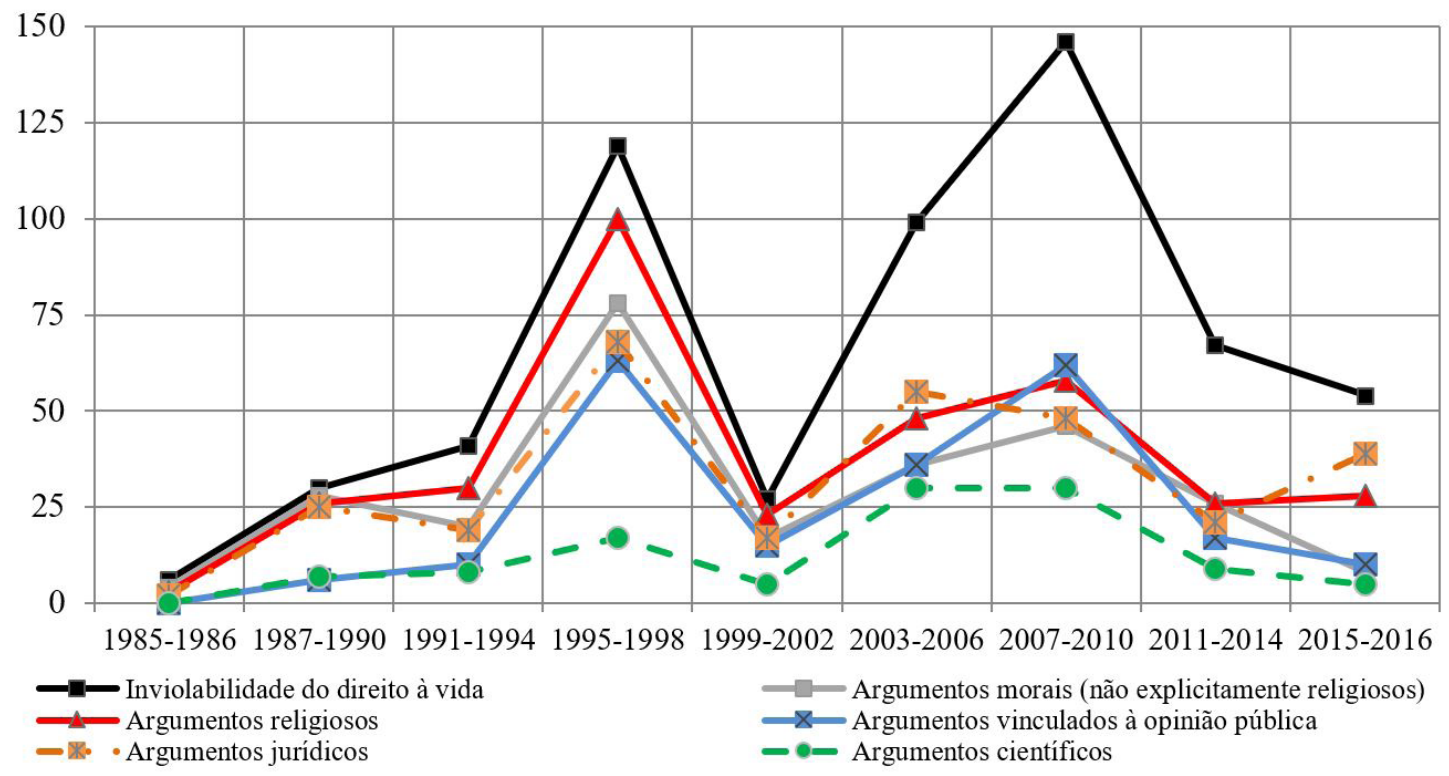

Fonte: Elaboração própria com base nos dados do projeto "Direito ao aborto e os sentidos da maternidade: atores e posições em disputa no Brasil contemporâneo", financiado pelo edital MCTI/CNPq/SPM-PR/MDA n. 32/2012.

\section{Gráfico 6}

Distribuição dos argumentos mobilizados com posiçóes contrárias ao aborto por legislatura no Uruguai (1985-2016)

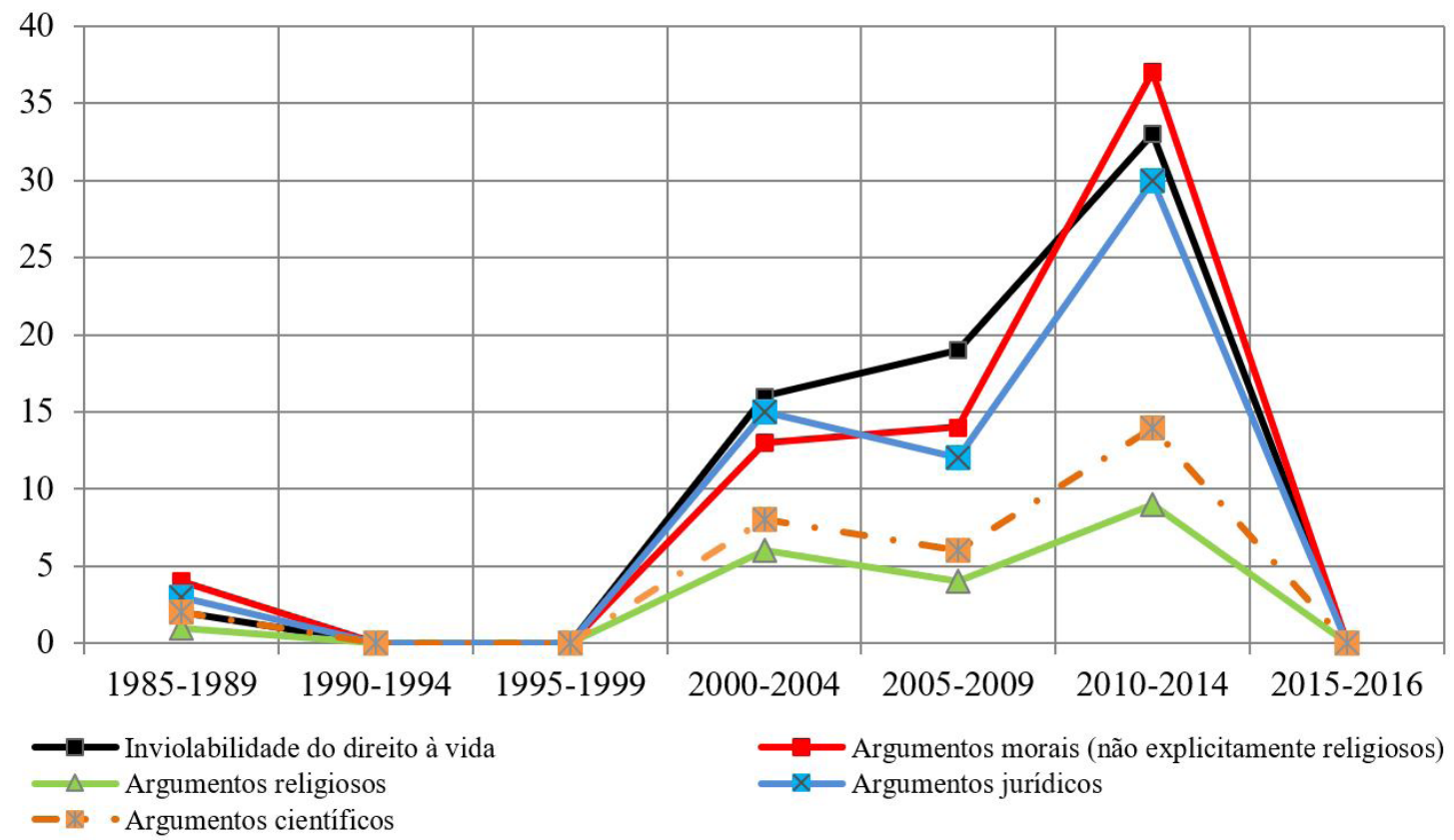

Fonte: Elaboração própria com base nos dados do projeto "Direito ao aborto e os sentidos da maternidade: atores e posiçóes em disputa no Brasil contemporâneo", financiado pelo edital MCTI/CNPq/SPM-PR/MDA n. 32/2012. 
em declaraçóes emitidas na década de 1970, pelos episcopados católicos de Estados Unidos, Holanda, França e Áustria. Já os pesquisadores Jeremy N. Thomas e Daniel V. A. Olson (Thomas e Olson, 2012) apresentaram evidências quanto à mudança na fonte de argumentos das lideranças religiosas dos Estados Unidos com relação à homossexualidade. Os autores diagnosticaram a significativa diminuição no uso de passagens bíblicas para condenar essa forma de exercício da sexualidade, especialmente a partir da década de 1980. Desde então, os argumentos oriundos de medicina, psicologia e psiquiatria passaram a ser empregados para alegar que a homossexualidade é fruto de disfunçóes e distúrbios comportamentais. Por seu turno, Julieta Ripoll (2013) identificou na análise das manifestações na Comissão Interamericana de Direitos Humanos (CIDH), ocorrida na Costa Rica, em 2012, a ausência de referências explícitas a sistemas de crenças; e as argumentaçóes se organizaram sobre bases estritamente jurídicas, ainda que amparadas em pressupostos religiosos para expressar oposição à fertilização in vitro e ao aborto. As manifestaçóes na $\mathrm{CIDH}$ ratificaram a interpretaçâo da defesa do direito à vida desde a concepção como direito humano e princípio constitucional dos países-membros, assim como o compromisso firmado em outros tratados por países signatários, como o Pacto de San Jose da Costa Rica, na Convenção Americana de Direitos Humanos, de 1969, um dos acordos mais citados.

A construção argumentativa dos(as) movimentos e parlamentares contrários ao aborto sustentam os direitos absolutos e exclusivos do embrião, seja pelo enquadramento de sua condição enquanto sujeito de direito, seja por sua individualidade com base no DNA e proteínas do zigoto (Emmerick, 2013; Rostagnol, 2008). As mulheres, por sua vez, em nenhum momento são tratadas como pessoas concretas e sujeitas plenas de direitos (Machado, 2017; Jones, 2007). Nessa narrativa, são pontuados apenas os deveres das mulheres, encarregadas de cumprir a "sagrada" missão da maternidade, em suma, postulando o retorno da mulher ao lugar tradicional de subordinação, em que seus direitos sexuais e reprodutivos não são legítimos e reconhecidos (Machado, 2017; Rostagnol, 2008).

Antes de qualquer coisa, é interessante notar o diagnóstico de um padrão muito similar na mobilização de argumentos de cunho jurídico e científico para, na verdade, respaldar concepçóes religiosas. Esse padrão é identificado em investigaçôes realizadas no Poder Legislativo do Brasil (Emmerick, 2013; Luna, 2014; Machado, 2017; Miguel et al., 2017) e do Uruguai (Jones, 2007; Rostagnol, 2008), assim como em análises comparativas entre os países da América Latina (Ruibal, 2014; Rocha et al., 2009). Essa constatação demonstra certa coesão na atuação de grupos contrários ao aborto e notável capacidade de mobilização em nível transnacional (Ruibal, 2014).

Mesmo identificando a existência desse fenômeno nos discursos proferidos no Brasil e no Uruguai, é necessário mensurar diferenças expressivas no tocante à comparação dos países nesse aspecto. Ao examinar o gráfico 5 referente ao Brasil observamos que os argumentos de conotação e matriz religiosa representam importante base dos discursos proferidos em plenário. Em boa parte das vezes, esses argumentos fundamentaram posições regressivas sobre o aborto. Para ser mais exato, $75 \%$ dos pronunciamentos (216 de 288) com posição a favor da restrição do aborto legale por novas medidas punitivas elou controle foram amparados por argumentos como inviolabilidade do direito à vida, religiosos e morais (nâo explicitamente religiosos). Ao analisar o gráfico 5 com os dados referentes às legislaturas de 1995 a 1997 e aqueles aferidos nas legislaturas ocorridas nos anos 2000 (sobretudo, de 2007 a 2010), percebemos certa diminuição na frequência de citações de argumentos religiosos; além disso, nesse período os argumentos jurídicos e científicos passaram a ser evocados com maior recorrência para sustentar as posições contrárias.

Mesmo assim, ao examinar a tabela $6 \mathrm{com}$ os argumentos empregados como principais nos pronunciamentos, percebemos que é significativa a proeminência de elaborações que visam conduzir o debate por ângulos explicitamente religiosos e/ou morais. Por exemplo, as categorias inviolabilidade do direito à vida, argumentos religiosos e argumentos morais (não explicitamente religiosos), quando somadas, alcançam a expressão numérica de 510 registros. O que significa dizer, que $47,4 \%$ (de 1.078 ) dos pronunciamentos realizados no Brasil sobre o aborto empregaram esses argumentos como os eixos principais na construção das falas. Já havíamos exposto que esses 
argumentos estavam entre os mais citados, porém o que não sabíamos era a relevância deles, pois, apesar de mencionados frequentemente, poderiam muito bem ocupar um lugar periférico, em vez do expressivo protagonismo ao serem mobilizados como base principal de sustentação nas falas.

Sendo assim, essa reconfiguração da base de sustentação dos discursos é perceptível, no entanto, é um movimento em consolidação nos pronunciamentos na Câmara dos Deputados do Brasil, sobretudo quando comparados aos pronunciamentos uruguaios. Dito isso, tendo em vista que na série histórica os pronunciamentos que mobilizam argumentos jurídicos e a ciência se tornaram frequentes a partir de 2005 em comparação aos argumentos religiosos e morais, as falas com ênfase em argumentos morais e religiosos diminuíram em comparação com a década de 1990 , mas permaneceram sendo mobilizadas com razoável constância. A reconfiguração na base de sustentação dos discursos no Brasil teve como intuito a conquista de legitimidade no debate público sobre o aborto; esse processo está relacionado, como dito anteriormente, ao contexto de açóes do Poder Executivo para regulamentar e rever a legislação sobre o aborto, por meio de norma técnica do Ministério da Saúde e da comissão tripartite, a aprovação nos poderes Judiciário e no Legislativo da Lei de Biossegurança, que autorizou a extração de células-tronco embrionárias de embrióes restantes de reprodução assistida, e a decisão do Poder Judiciário sobre os anencéfalos (Emmerick, 2013; Luna, 2014).

No Uruguai há panorama mais definido a respeito desse processo de transfiguração discursiva dos pressupostos religiosos a outros sistemas de valores. Os argumentos religiosos são extremamente periféricos no conjunto de fundamentaçôes no decurso das legislaturas, acrescentando o fato de que, em muitos casos, as manifestaçóes religiosas são realizadas apenas para pontuar um lugar de fala ou introduzir referências laterais à crença ou a Deus. Sendo assim, praticamente inexistem discursos que empregam máximas como "Só Deus dá a vida" ou "Só Deus pode tirá-la” ou que se baseiam na bíblia para atestar o valor supremo da vida. Obviamente, isso não significa que os elementos estruturantes desse tipo de acepção estejam plenamente ausentes, o que podemos constatar é que são enunciados de outra forma.

Segundo Juan Marco Vaggione (2009, 2012), o apelo a recursos argumentativos cujas fontes são de matrizes seculares é também decorrente dos limites demarcados pela laicidade do Estado, enquanto construção normativa do político. Nessa situação, não se trata apenas de reforçar o princípio da laicidade diante do vigoroso ativismo religioso, mas de interrogar sobre a legitimidade de sua atuação no interior do processo democrático (Silva, 2019).

\section{Consideraçôes finais}

O mapeamento dos discursos na Câmara dos Deputados e na Câmara de Representantes contribui para explicar, até certo ponto, os cenários vigentes nesses países no tocante à agenda dos direitos reprodutivos das mulheres. De modo específico, após a redemocratização, são expostos indicadores para compreender por que no Uruguai a descriminalização da interrupção voluntária da gravidez foi aprovada e no Brasil as ampliaçóes na legislação sobre o direito ao aborto, como a permissão do aborto em fetos diagnosticados com anencefalia, são promovidas na esfera do Poder Judiciário e as propostas de regulamentaçóes dos casos já previstos em lei pelo Poder Executivo são levadas a discussões no Poder Legislativo, que se direcionam majoritariamente para a aplicação de maiores restriçôes ao aborto.

As dinâmicas político-sociais são, em grande medida, essenciais na explicaçáo do panorama aferido pelos dados. É possível estabelecer uma relação intrínseca entre atuação e interlocução de movimentos sociais, sociedade civil e grupos parlamentares com a conformação da deliberação pública no Poder Legislativo sobre a interrupção voluntária da gravidez. No Uruguai essa relaçáo é impulsionada de forma proeminente pelos movimentos feministas e pelos(as) parlamentares da Frente Ampla; no Brasil isso se dá por grupos denominados pró-vida, instituições religiosas e integrantes das frentes confessionais na Câmara dos Deputados.

É relevante ponderar também a configuração da laicidade do Estado nesses países como variável central para analisar os resultados aferidos, principalmente na 
avaliação das inflexões adotadas pelos(as) parlamentares para elaborar seus pronunciamentos sobre a interrupção voluntária da gravidez. No âmbito da ampliação dos direitos reprodutivos, há notável diferença entre os países: no Uruguai os pronunciamentos sustentam, em grande medida, o direito à interrupção voluntária da gravidez na relação entre aborto e liberdades laicas, isto é, a liberdade de consciência e autonomia das mulheres para decidir sobre seus corpos; no Brasil há uma tendência de moderação nos pronunciamentos, também identificada nos resultados de pesquisa de Ruibal (2014) e Luna (2014), ou seja, dando enfoque a questôes relevantes de saúde pública, mas pontuando de forma muito lateral o aborto como direito a autodeterminação moral e liberdade de consciência. No outro espectro da discussão, com maior volume de evidências, o espaço das convicçóes religiosas e morais é característica singular na composição dos discursos. Por mais que no legislativo uruguaio haja grupos e oposiçóes ao aborto, a consolidação da laicidade demonstra ter impacto nos limites, termos e parâmetros em que se organizam as construçóes discursivas. Já no Brasil, sua instável constituição contribui para elaboraçóes de cunho regressivo, na maioria das vezes respaldadas pelas crenças religiosas dos(as) parlamentares.

De acordo com Roberto Blancarte (2008), a laicidade do Estado se configura propriamente como regime social de convivência baseado na liberdade de consciência, cujas instituiçóes públicas estão legitimadas, principalmente, pela soberania popular e não por elementos religiosos. Assim, os fatores fundamentais para identificar a constituição da laicidade do Estado são o grau de autonomia e as fontes de legitimação mobilizadas pelo sistema político, nesse caso, na figura de seus representantes na Câmara dos Deputados, para se posicionar sobre assuntos de natureza pública. A existência de uma norma jurídica que estipule a laicidade do Estado na Constituição é incapaz, por si só, de assegurar seu desenvolvimento. Essa conclusão é derivada do argumento de que a transição da fonte de legitimação do sistema político de formas sagradas para formas democráticas é resultado de um processo, cujo envolvimento das forças políticas e sociais é singular na construção da laicidade, assim como da democracia. Logo, as modificaçóes em seu desenho estão abertas.

Nessa perspectiva, a construção do Estado laico está intrinsecamente ligada aos direitos sexuais e reprodutivos, pela obrigação do Estado de assegurar a liberdade de consciência, impedindo que alguém seja obrigado a acreditar em algo (Silva, 2019). Do mesmo modo, a liberdade de consciência promove na sociedade uma pluralidade de ideias, religiosas ou seculares, as quais submetem algumas crenças à relativização no espaço público e à criação de juízos morais e de conduta aceitáveis por todos, alheios a uma doutrina específica (Machado, 2017; Emmerick, 2013). Nesse sentido, o sistema político, na figura de seus representantes, não possui atribuição para adotar políticas que venham a impor uma visão de mundo à sociedade, legitimando uma concepção moral em detrimento das outras. Isso significa dizer que o Estado laico não deve obrigar as mulheres a acreditar que estão cometendo um crime nem relegando um dom divino ao interromper uma gestação por sua livre decisão, tampouco as forçar a abortar (por exemplo, por razóes demográficas ou eugenia), uma vez que esse ato é contrário a suas crenças morais fundamentais.

\section{Agradecimentos}

Agradeço imensamente a colaboração e as sugestóes realizadas pelas professoras Flávia Biroli, minha orientadora, Maria José Rosado-Nunes, Tânia Mara de Almeida, Danusa Marques, Susana Rostagnol, bem como e aos pareceristas anônimos da RBCS. Agradeço à equipe editorial da RBCS e aos professores Priscilla Leine, Olívia Cristina Perez e Bruno Speck, pela atenção e compreensão em todo o processo envolvido até aprovação do texto, assim como a Cátia de Almeida, revisora da RBCS, pelas contribuiçôes na correção, adequação e aprimoramento do texto. Agradeço também às agências de fomento à pesquisa CAPES, CNPq e FAP/DF, por possibilitarem de diferentes formas a realização desta investigação.

Financiado pelo edital MCTI/CNPq/SPM-PR/ MDA n. 32/2012, coordenado pela professora Flávia Biroli e pelo professor Luis Felipe Miguel (Brasil, 2012a) 


\section{Notas}

1 O software Sphinx Lexica, versão 5.1, permite realizar definição de questôes fechadas, abertas e numéricas; agrupamento de questôes; cruzamento e preparação de variáveis (combinar, transformar e fundir); tabelas de análise simples descritiva, médias, correlaçóes, variância e regressão; tabela léxica; reagrupamento de léxicos; verbatim (extração de textos); elaboração de relatórios descritivos; elaboraçáo de gráficos distintos.

2 Fatos internos são, por exemplo, iniciativas políticas e jurídicas e projetos de lei provenientes dos poderes constituídos que adquirem notoriedade no âmbito legislativo. Já os externos se referem, por exemplo, a manifestaçóes sociais, religiosas e fatos que acontecem na sociedade e se tornam matéria de discussão.

3 Cabe ressaltar que até 2012 (ano em que foi aprovada a descriminalização do aborto), nenhum projeto de lei com o objetivo de restringir ou reprimir o aborto foi apresentado.

4 São eles: PL 2.755/2008, que tinha por objetivo garantir o direito à vida e fornecer recursos para as famílias manterem e educarem seus(suas) filhos(as), arquivado em com base no art. 147, em 2010 e 2015; PL 559/2010, que visava garantir o direito de liberdade de consciência, sobretudo a profissionais da saúde, arquivado e desarquivado em 2015; PL 56/2015, que buscava garantir e proteger a vida desde a concepção.

5 Por otra parte, algunos se preguntan por qué actuar simultáneamente en los aspectos educativos y en el de la despenalización. ¿¿Por qué no actuar primero en lo educativo, evaluar los resultados de un posible plan a cinco ańos, por ejemplo, y en una segunda etapa proponernos estudiar y quizás aprobar un proyecto de este tipo?

En primer lugar, los efectos de cualquier programa o plan educativo son a largo o mediano plazo y no inmediatos. Entonces, las respuestas son muy claras. A mi juicio, son de dos órdenes. La primera es que llevamos sesenta y cuatro ańos de vigencia de esta ley, con distintos Gobiernos, algunos con coincidencias ideológicas, políticas; pero sobre este tema llevamos sesenta y cuatros años y tenemos una práctica social sobre la cual existe un diagnóstico consensuado que demuestra que no se ha alcanzado el efecto que se pretendía, por lo menos en la letra. ¡Vaya si se habrá tenido tiempo de implementar esas políticas educativas que ahora se reclaman! (Uruguay, Diarios de Sesiones, 27 nov. 2002, p. 38)

6 Em muitas situaçôes, esses posicionamentos contrários utilizam base argumentativa similar àquelas evocadas por movimentos e parlamentares que denunciavam as açôes de controle populacional, obviamente com conotação semântica adversa, isto é, promoviam políticas de educação sexual e planejamento familiar para impedir que organizaçóes internacionais tratassem da descriminalização do aborto em seus respectivos países.

7 Para obter o número de posiçôes contrárias, foram fundidas três categorias: contra o aborto (genérico), a favor da restrição do aborto legal e por novas medidas punitivas elou de controle.

8 O Ato da Mesa n. 69, de 2005, estipulou o registro e a institucionalizaçáo dos grupos parlamentares por meio de frentes/bancadas temáticas, de caráter suprapartidário, compostas de pelo menos 171 signatários (um terço de 513).

9 Entre 1985 e 2016, os(as) parlamentares do Partido Nacional efetuaram 91 pronunciamentos, nenhum deles a favor da ampliação do aborto legal.

10 Decía (Luiz Pérez Aguirre): "El aborto es y parece querer permanecer una tozuda (em PT: teimosa) y trágica realidad social". (...) "La mortalidad por aborto afecta a las mujeres pobres porque solo tienen acceso económico a un aborto clandestino sin las mínimas garantías. Es evidente que son las mujeres pobres las que mueren en los abortos clandestinos. Mientras no logremos un análisis serio de las causas y las condiciones socioeconómicas y culturales del aborto, mientras no iniciemos un proceso responsable de obligatorio ajuste social para eliminarlas, todo juicio y castigo a las supuestas culpables no pasa de ser un fariseísmo moralista que se lava las manos y la conciencia.- $\mathrm{Si}$ somos realistas, tenemos que aceptar la evidencia de que la realidad no se ajusta a justicia y no es por tanto posible dar respuestas morales efectivas únicas e iguales para todos los casos". (Uruguay, Diario de Sesiones, 10/12/2002, p. 55).

\section{REFERÊNCIAS}

ABRACINSKAS, Lilián \& GÓMEZ, Alejandra. (2007), "Desde la arena feminista hacia la escena política", in L. Abracinskas \& A. Gómez (org.), Aborto en debate: dilemas y desafios del Uruguay democrático-proceso político y social, 2001-2004, Montevidéu, Mujer y Salud en Uruguay, p. 11-30.

BIROLI, Flávia. (2014), "O debate sobre o aborto", in F. Biroli \& L. F. Miguel, Feminismo e politica; uma introdução, Sáo Paulo, Boitempo, p. 123-130.

BIROLI, Flávia. (2018), "Aborto, sexualidade e autonomia”, in F. Biroli, Gênero e desigualdades: limites da democracia no Brasil, São Paulo, Boitempo, p. 133-169.

BIROLI, Flávia \& MIGUEL, Luis Felipe. (2016), Aborto e democracia. São Paulo, Alameda. 
BLANCARTE, Roberto. (2008), "El porqué de un Estado Laico", in R. Blancarte, Los retos de la laicidad y la secularización en el mundo contemporáneo, México, Colegio de México, p. 29-46.

BRASIL. Congresso Nacional. Câmara dos Deputados. (2012a), Regimento interno da Câmara dos Deputados. Brasília, DF, Ediçóes Câmara.

BRASIL. Ministério da Ciência e Tecnologia. Conselho Nacional de Desenvolvimento Científico e Tecnológico. (2012b), Chamada MCTI/CNPq/SPM-PR/MDA n. 32/2012. Disponível em http://www.cnpq.br/web/guest/ chamadas- publicas?p_p_id=resultadosportlet_ WAR_ resultadoscnpqportlet_ INSTANCE_ $0 Z$ aM\&filtro $=$ encerradas $\&$ detalha $=$ chamada Divulgada\&idDivulgacao $=2201$, consultado em 17/11/2020.

BRASIL. Câmara dos Deputados. (2020a), Frentes parlamentares. Disponível em https://www. camara.leg.br/internet/deputado/frentes.asp, consultado em 11/11/2020.

BRASIL. Câmara dos Deputados. (2020b), Diários da Câmara dos Deputados. Disponível em http://imagem.camara.leg.br/diarios.asp?termo =copyright\&pesquisar=, consultado em 16/11/2020.

BARSTED, Leila. (2009), "O movimento de mulheres e o debate sobre o aborto", in Maria I. B. da Rocha \& R. M. Barbosa, Aborto no Brasile países do Cone Sul: panorama da situação e dos estudos acadêmicos, Campinas, SP, Editora Unicamp, p. 228-256.

DINIZ, Debora. (2003), "Quem autoriza o aborto seletivo no Brasil? Médicos, promotores e juízes em cena". Physis: Revista de Saúde Coletiva, 13, 2: 251-272. https://doi.org/10.1590/S010373312003000200003.

DINIZ, Debora \& VÉLEZ, Ana. (2008), “Aborto na Suprema Corte: o caso da anencefalia no Brasil". Revista Estudos Feministas, 16, 2: 647-652. http://dx.doi.org/10.1590/S0104026X2008000200019.

EMMERICK, Rulian. (2013), Religião e direitos reprodutivos: o aborto como campo de disputa politica e Religiosa. Rio de Janeiro, Editora Lumen Juris.

JOHNSON, Nikki, ROCHA, Cecilia \& SCHENCK, Marcela. (2015), La inserción del aborto en la agenda político-pública uruguaya 1985-2013: un análisis desde el movimiento feminista. Montevidéu, Cotidiano Mujer.

JONES, Daniel. (2007), "El debate parlamentario sobre la ley de Defensa de la Salud Reproductiva en Uruguay (2002-2004)", in L. Abracinskas \& A. Gómez (org.), Aborto en debate: dilemas y desafíos del Uruguay democrático - proceso politico y social 2001-2004, Montevidéu, Mujer y Salud en Uruguay, p. 53-98.

GUIGOU, Nicolás. (2011), "Religião e política no Uruguai”, in A. P. Oro (org.), Religiáo e política no Cone Sul, São Paulo, Attar Editorial, p. 157-222.

HTUN, Mala. (2003), Sex and the State: abortion, divorce, and the family under Latin American dictatorships and democracies. Cambridge, Cambridge University Press.

LANZARO, Jorge. (2003), "Os partidos uruguaios: a transição na transição". Opiniāo Pública, 9, 2: 46-72. http://dx.doi.org/10.1590/S010462762003000200003.

LUNA, Naara. (2010), "Aborto e células-tronco embrionárias na campanha da fraternidade: ciência e ética no ensino da Igreja”. Revista Brasileira de Ciências Sociais, 25, 74: 91-105. http://dx.doi. org/10.1590/S0102-69092010000300006.

LUNA, Naara. (2014), “Aborto no Congresso Nacional: o enfrentamento de atores religiosos e feministas em um Estado laico". Revista Brasileira Ciência Politica, 14: 83-109. https:// doi.org/10.1590/0103-335220141404.

MACHADO, Lia Zanotta. (2017), "O aborto como direito e o aborto como crime: o retrocesso neoconservador". Cadernos Pagu, 50: e17504. https://doi.org/10.1590/18094449201700500004.

MACHADO, Maria das Dores Campos. (2012), "Religiāo, cultura e política". Religião \& Sociedade, 32, 2: 29-56. http://dx.doi.org/10.1590/S010085872012000200003.

MARIANO, Rayani \& SILVA, Luis Gustavo Teixeira. (2017), "O direito à vida como ponto de partida para a análise do debate parlamentar sobre o aborto no Brasil e no Uruguai”. Revista Gênero, 17, 1:139-169.

MIGUEL, Luis Felipe (2012), "Aborto e democracia". Estudos Feministas, 20, 3: 657-672. https://doi. org/10.1590/S0104-026X2012000300004. 
MIGUEL, Luis Felipe, BIROLI, Flávia \& MARIANO, Rayani. (2017), "O direito ao aborto no debate legislativo brasileiro: a ofensiva conservadora na Câmara dos Deputados". Opiniáo Pública, 23, 1: 230-260. https://doi.org/10.1590/180701912017231230.

RIPOLL, Julieta. (2013), "Laicidad y resistencia: movilización católica contra los derechos sexuales y reproductivos en las Américas", in P. S. Ugarte \& P. Capdeville, Para entender y pensar la laicidad, México, Editorial Miguel Ángel Porrúa, p. 153-210.

ROCHA, Maria Isabel, ROSTAGNOL, Susana \& GUTIÉRREZ, María Alicia. (2009), "Aborto y Parlamento: un estudio sobre Brasil, Uruguay y Argentina”. Revista Brasileira de Estudos Populacionais, 26, 2: 219-336. https://doi.org/10.1590/S010230982009000200005.

ROSADO-NUNES, Maria José. (2012), “O tema do aborto na Igreja Católica: divergências silenciadas". Ciência e Cultura, 64, 2: 23-31. http://dx.doi. org/10.21800/S0009-67252012000200012.

ROSTAGNOL, Susana. (2008), "El conflicto mujerembrión en debate parlamentario sobre el aborto". Revista Estudos Feminista, 16, 2: 667-674. http:// dx.doi.org/10.1590/S0104-026X2008000200022.

ROSTAGNOL, Susana. (2009), "Panorama do aborto no Uruguai", in M. I. B. da Rocha \& R. M. Barbosa, Aborto no Brasil e paises do Cone Sul: panorama da situação e dos estudos acadêmicos, Campinas, SP, Editora Unicamp, p. 91-109.

RUIBAL, Alba. (2014), "Feminismo frente a fundamentalismos religiosos: mobilização e contramobilização em torno dos direitos reprodutivos na América Latina”. Revista Brasileira Ciência Politica, 14: 111-138. https:// doi.org/10.1590/0103-335220141405.

SELIOS, Lucía. (2007), "La opinión pública, la democracia representativa y el aborto", in L. Abracinskas \& A. Gómez (org.), Aborto en debate: dilemas y desafíos del Uruguay democrático - proceso político y social 2001-2004, Montevidéu, Mujer y Salud en Uruguay, p. 151-166.

SILVA, Luis Gustavo Teixeira. (2017a), "O desenho da pesquisa: o debate legislativo sobre o aborto no Brasil e no Uruguai". Revista Teoria \& Pesquisa, 26, 3: 235-251.

SILVA, Luis Gustavo Teixeira. (2017b), "Religião e Política no Brasil". Latinoamérica. Revista de Estudios Latinoamericanos, 64: 223-256. https://doi. org/10.22201/cialc.24486914e.2017.64.56799.

SILVA, Luis Gustavo Teixeira. (2019), "Laicidade do Estado: dimensóes analítico-conceituais e suas estruturas normativas de funcionamento". Sociologias, 21, 51: 278-304. https://doi. org/10.1590/15174522-0215113.

THOMAS, Jeremy N. \& OLSON, Daniel V. A. (2012), "Evangelical Elites' Changing responses to homosexuality 1960-2009". Sociology of Religion, 73, 3: 239-272. https://doi.org/10.1093/socrel/ srs031.

URUGUAY. (2014), Reglamento de la Cámara de Representantes. Montevidéu, Cámara de Representantes.

URUGUAY. Parlamento. (2016), Diarios de Sesiones. Disponível em https://parlamento.gub.uy/ camarasycomisiones/representantes/plenario/ documentos/diarios-de-sesion, consultado em 16/11/2020.

VAGGIONE, Juan Marco. (2009), Sexualidad, religión y política en América Latina. Trabalho apresentado no encontro Diálogos Regionales, Rio de Janeiro, agosto. Disponível em https:// laicismo.org/data/docs/archivo_923.pdf, consultado em 11/11/2020.

VAGGIONE, Juan Marco. (2012), "La 'cultura de la vida': desplazamientos estratégicos del activismo católico conservador frente a los derechos sexuales y reproductivos". Religiāo \& Sociedade, 32, 2: 57-80. https://doi.org/10.1590/S010085872012000200004 . 


\section{O DEBATE SOBRE O ABORTO NA CÂMARA DOS DEPUTADOS DO BRASIL E DO URUGUAI (1985- 2016)}

\section{Luis Gustavo Teixeira da Silva}

Palavras-chave: Aborto; Democracia; Direitos individuais; Laicidade do Estado; Brasil; Uruguai.

O objetivo deste texto é analisar e comparar o debate legislativo sobre o aborto realizado no Brasil e no Uruguai. Para realizar esta investigação, utilizamos como metodologia de pesquisa a análise de todos os discursos proferidos na Câmara dos Deputados do Brasil e na Câmara de Representantes do Uruguai, entre os anos de 1985 e 2016. A comparação entre esses países é relevante por serem casos opostos no tocante ao tratamento dos direitos reprodutivos das mulheres. O Uruguai se tornou o único país da região, em período recente, a aprovar uma legislação para descriminalizar da interrupção voluntária da gravidez. Já no Brasil verifica-se a ascensão de forças políticas, sociais e religiosas conservadoras, as quais são, em grande medida, responsáveis por conduzir de modo regressivo a discussão sobre o aborto no Poder Legislativo. Nesse sentido, propomos examinar as posiçóes em disputa e, por meio dos dados, apresentar indicadores para explicar esses distintos cenários.

\section{THE DEBATE ON ABORTION AT BRAZIL AND URUGUAY'S CHAMBER OF DEPUTIES (1985- 2016)}

\section{Luis Gustavo Teixeira da Silva}

Keywords: Abortion; Democracy; Individual rights; Laicity of the State; Brazil; Uruguay.

The aim of this text is to analyze and compare the legislative debate on abortion in Brazil and Uruguay. To this end, a research methodology comprising the analysis of all speeches made in Brazil's Chamber of Deputies and in Uruguay's Chamber of Representatives between 1985 and 2016 was applied. The comparison between these countries is relevant because they are opposed to the treatment of women's reproductive rights. Uruguay has recently become the only country in the region to pass a legislation to decriminalize voluntary pregnancy termination. Brazil, on the other hand, has exhibited increasing conservative political, social and religious forces, which are, to a large extent, responsible for the regressive discussion on abortion in the Legislative Branch. In this sense, we propose to examine disputed positions and, through the obtained data, present indicators to explain these different scenarios.

\section{LE DÉBAT SUR L'AVORTEMENT AUX CHAMBRES DES DÉPUTÉS DU BRÉSIL ET DE L'URUGUAY (1985-2016)}

\section{Luis Gustavo Teixeira da Silva}

Mots-clés: Avortement ;Démocratie; Droitsindividuels; Laïcité de l'Etat; Brésil; Uruguay.

Ce texte propose une analyse comparative du débat législatif sur l'avortement réalisé au Brésil et en Uruguay, et ce, à travers l'examen de tous les discours prononcés à la Chambre des députés au Brésil et à la Chambre des représentants en Uruguay entre 1985 e 2016. La comparaison est importante parce que le traitement des droits reproductifs des femmes est totalement différent entre les deux pays. L'Uruguay est le seul pays de la région à avoir approuvé récemment une loi sur la dépénalisation de l'interruption volontaire de grossesse. Au Brésil, par contre, l'ascension de forces conservatrices politiques, sociales et religieuses est en grande partie responsable d'une régression de la discussion sur l'avortement par le pouvoir législatif. L'objectif de ce travail est d'analyser les positions contraires et, à travers les données obtenues, de présenter des indicateurs pour expliquer ces différents scénarios. 


\section{Anexo I}

Ficha de preenchimento dos discursos sobre o aborto no Brasil e no Uruguai

\section{DOCUMENTAÇÃO}

\begin{tabular}{|c|c|c|c|}
\hline 1. N. do discurso/Executante & 2. Página & 3. Ano (exemplo) & \\
\hline Para uso interno, para organizar as atividades de & & o 1985 & о 2001 \\
\hline investigação & & o 1986 & o 2002 \\
\hline 4. Mês & 5. Dia do pronunciamento & o 1987 & o.... \\
\hline & & o 1988 & o 2015 \\
\hline A resposta deve ser entre 1 e 12 . & $A$ resposta deve ser entre 1 e 31 . & $0 \ldots$ & o 2016 \\
\hline
\end{tabular}

\begin{tabular}{lll}
\hline & 6. Expediente (Brasil) & 6. Sessáo Legislativa (Uruguai) \\
\hline o Grande Expediente & o Ordem do Dia & o Sessão Ordinária \\
o Pequeno Expediente & o Comunicaçóes Parlamentares & o Sessão Extraordinária \\
& o Comunicaçóes Lideranças & o Sessão Especial
\end{tabular}

$\begin{array}{lcl}\text { 7. Nome do(a) parlamentar } & \text { IDENTIFICAÇÁO } & \text { 9. Em caso de aparte, o orador } \\ \text { aparteado era: }\end{array}$

\begin{tabular}{|c|c|c|c|}
\hline \multicolumn{3}{|l|}{ 10. Partido } & \multirow{3}{*}{$\begin{array}{l}\text { 13. UF (BR - exemplos): } \\
\text { o Rio Grande do Sul } \\
\text { o São Paulo }\end{array}$} \\
\hline & emplo) & Uruguai & \\
\hline o PCdoB & o PT & o Frente Amplia & \\
\hline o PMDB & o PSB & o Partido Nacional & o Bahia \\
\hline o PDT & o PSDB & o Partido Colorado & o Distrito Federal \\
\hline o PFL/DEM & o Outro & o Outro & \\
\hline \multirow{5}{*}{\multicolumn{2}{|c|}{ 11. Se outro partido, qual? }} & 12. Mandato & 13. Departamento (UY - exemplos): \\
\hline & & o Primeiro & o Montevidéu \\
\hline & & o Segundo & o Canelones \\
\hline & & o Terceiro & o Rivera \\
\hline & & o Quarto ou mais & \\
\hline
\end{tabular}

\section{CONTEÚDO DO DISCURSO}

14. Palavra-chave:
o 1. Aborto
o 2. Abortamento
o 3. Interrupção voluntária da gravidez
o 4. Interrupção da gravidez
o 5. Interrupção da gestação
o 6. Interrupção voluntária da gestação

\section{O aborto é tema:}

\section{O discurso se coloca:}

o 1. A favor da ampliação do aborto legal

o 2. A favor da manutenção do aborto legal

o 3. A favor da restrição do aborto legal o Focado

o Um entre vários

o Secundário de outro foco

o Referência lateral

o Irrelevante

\footnotetext{
Você pode marcar duas alternativas. A resposta é obrigatória.
}

o 4. Contra o aborto (genérico)

o 5. Por novas medidas punitivas e/ou de controle

o 6. Pela educação sexual e/ou planejamento familiar 


\section{Caso seja a favor da ampliaçáo do aborto:}

o 1. Descriminalização total

o 2. Permissão em caso de inviabilidade do feto

o 3. Ampliaçáo da rede de assistência hospitalar

o 4. Não indica que tipo de ampliação

o 5. Outra ampliação

19. Caso seja a favor da restriçáo do aborto legal e/ou de novas medidas punitivas:
o 1. Proibição total

o 2. Estupro

o 3. Risco de vida da gestante

o 4. Inviabilidade do feto

o 5. Políticas de repressão ao aborto

o 6. Não indica que tipo de restrição

o 7 . Outra restrição

\section{Se outra ampliaçáo, qual?}

20. Se outra restriçáo, qual?

\section{Tipos de argumentos assumidos pelo(a) parlamentar:}

o 1 . Argumentos religiosos

23. Qual é o argumento principal do discurso?

25. O discurso se coloca contra

o 9. Injustiça social algum tipo de argumento?

o 2. Argumentos científicos

o 3. Aborto é uma questão de saúde pública

o 10. Argumentos morais (não explicitamente religiosos)

o 11. Argumentos vinculados à opinião pública

o 4. Liberdade individual

o 5 . Controle da mulher sobre o próprio corpo

o 6. Argumentos jurídicos

o 12. Controle da natalidade como estratégia imperialista

o 13. Laicidade do Estado

o 14. Outro

o 15. Nenhum

o 7. Argumentos econômicos

o 8. Inviolabilidade do direito à vida

As variáveis 21, 23 e 25 são respondidas com os mesmos argumentos, a diferença é sua função na classificação.

\section{Outro argumento, qual? \\ 24. Outro principal, qual? \\ 26. Outro contra-argumento,} qual?

27. Autoidentificaçáo como argumento de autoridade:

\begin{tabular}{ll}
\hline o 1 . Máe & o 5 . Jurista \\
o 2. Mulher & o 6. Cientista \\
o 3. Médico(a) & o 7. Outra \\
o 4. Sacerdote & o 8. Nenhuma
\end{tabular}

28. Outra identificaçáo, qual?

29. $O$ discurso se baseia em algum fato do momento?

\section{Brasil (exemplos)}

o PEC $25 / 95$

o Normas técnicas do MS

o CPI do aborto

o Marcha em defesa da vida

\author{
o STF e a anencefalia \\ o PL 20/91 \\ o Microcefalia \\ o Outro \\ o Nenhum
}

$\begin{aligned} & \text { Uruguai } \\ & \text { (exemplos) }\end{aligned}$
o PL 536/2006
o Mons. Cotugno
o Outro
o Nenhum

30. Outro fato, qual?

\begin{tabular}{ll}
\hline 31. Discurso & 32. Observaçóes \\
\hline Colocar o texto do pronunciamento na integra. & Expor alguma observação sobre o discurso. \\
\hline
\end{tabular}

